\title{
On several new or poorly-known Oriental Paradoxosomatidae (Diplopoda: Polydesmida), XVI
}

\section{О нескольких новых или плохоизученных ориентальных Paradoxosomatidae (Diplopoda: Polydesmida), XVI}

\author{
S.I. Golovatch \\ С.И. Головач
}

Institute for Problems of Ecology and Evolution, Russian Academy of Sciences, Leninsky prospekt 33, Moscow 119071 Russia. E-mail: sgolovatch@yandex.ru

Институт проблем экологии и эволюции РАН, Ленинский проспект, 33, Москва 119071 Россия.

KEY WORDS: Diplopoda, Polydesmida, Paradoxosomatidae, taxonomy, new records, new species, Nepal.

КЛЮЧЕВЫЕ СЛОВА: Diplopoda, Polydesmida, Paradoxosomatidae, таксономия, новые находки, новые виды, Непал.

ABSTRACT. This contribution is mainly devoted to descriptions of seven new species of Delarthrum from Nepal: D. beroni sp.n., D. typicum sp.n., D. curtum sp.n., D. tenuitergale sp.n., D. andreevi sp.n., $D$. heterotergale sp.n. and $D$. setosum sp.n. The following new synonymies are advanced: Nepalomorpha Golovatch, 1994, = Parorthomorpha Golovatch, 1994, = Martensosoma Golovatch, 1992, = Armolites Golovatch, 1984, = Orophosoma Jeekel, 1980, = Delarthrum Attems, 1936, all syn.n. A new diagnosis of and 40 new transfers to Delarthrum (tribe Polydrepanini) are provided, this genus currently encompassing as many as 41 species, mostly Himalayan. In addition, because of homonymy, D. spiniger (Golovatch, 1992) is renamed into D. spinigerum (Golovatch, 1992), nom.n., while Parorthomorpha panda Golovatch, 2009, from north-central China, is newly transferred to Polylobosoma Jeekel, 1980, to become Polylobosoma panda (Golovatch, 2009), comb.n. ex Parorthomorpha. Beronodesmus gen.n. is established for B. pallidus sp.n., the first genus and species of the Oriental tribe Chamberlinini to be reported from the Himalayas. This tribe possibly also comprises the obscure "Tonkinosoma" jeekeli Nguyen Duc, 2011, from northern Vietnam.

РЕЗЮМЕ. Данное сообщение в основном посвящено описаниям семи новых видов рода Delarthrum из Непала: D. beroni sp.n., D. typicum sp.n., D. curtum sp.n., D. tenuitergale sp.n., D. andreevi sp.n., D. heterotergale sp.n. и D. setosum sp.n. Предложены следующие новые синонимы: Nepalomorpha Golovatch, 1994, = Parorthomorpha Golovatch, 1994, = Martensosoma Golovatch, 1992, = Armolites Golovatch, 1984, = Orophosoma Jeekel, 1980, = Delarthrum Attems, 1936, все syn.n. Даны новый диагноз для и 40 новых перемещенияй в состав рода Delarthrum (триба Polydrepanini), который теперь вклю- чает 41 вид, в основном из Гималаев. Кроме того, из-за гомонимии название D. spiniger (Golovatch, 1992) переименовано в D. spinigerum (Golovatch, 1992), nom.n., а вид Parorthomorpha panda Golovatch, 2009 из северо-центральной части Китая впервые перенесен в состав рода Polylobosoma Jeekel, 1980, чтобы стать Polylobosoma panda (Golovatch, 2009), comb.n. ex Parorthomorpha. Beronodesmus gen.n. установлен для B. pallidus sp.n., первые род и вид из ориентальной трибы Chamberlinini, отмечаемые в Гималаях. Эта триба, возможно, включает и требующий ревизии вид “Tonkinosoma" jeekeli Nguyen Duc, 2011, из Северного Вьетнама.

\section{Introduction}

This paper mainly treats a collection of paradoxosomatid millipedes from Nepal, with new records of a few known, as well as to descriptions of eight new, species. One of the new species belongs to a new monobasic genus from an Oriental tribe hitherto never reported from the Himalayas, whereas the other new species belong to a large and redefined genus which appears to have several new junior subjective synonyms. The material has largely been returned to the collection of the National Museum of Natural History, Sofia, Bulgaria (NMNHS) where it belongs, with only a few duplicates retained for the holdings of the Zoological Museum, Moscow State University, Russia (ZMUM).

\section{Taxonomic part}

Anoplodesmus anthracinus (Pocock, 1896)

MATERIAL. $9 \sigma^{7} \sigma^{x}, 2$ +, 3 juv. (NMNHS), $2 \sigma^{x} \sigma^{x}$ (ZMUM ९2379), Myanmar, Mandalay, 3.11.1984, leg. P. Beron \& S. Andreev. 
REMARKS. This widespread tropical Asian species, originally described from Myanmar, has recently been reviewed and documented from Malay Peninsula, Malaysia and Sri Lanka [Golovatch \& Stoev, 2013]. Apparently, as a result of long conservation in alcohol the new samples are strongly faded, light grey-brown at most.

\section{Anoplodesmus martensi (Golovatch, 1990)} Figs 1-4.

MATERIAL. $1 \bigcirc^{7}, 2$ 우, 1 juv. (NMNHS), Nepal, Chandanbari, Langtang National Park, Lauri Bina, 14.07.1981; $1 \sigma^{7}, 1$ juv. (ZMUM 22383 ), same locality, Danje Guard Post, 3100 m a.s.l., 14.07.1981, all leg. P. Beron; 2 O $^{7} \mathrm{O}^{7}$ (NMNHS), same locality, 3500-3600 m a.s.1., 17.09.1984, leg. P. Beron \& S. Andreev.

REMARKS. This species has been described, and still remains known, from several localities in eastern Nepal [Golovatch, 1990]. The fresh samples can be considered as near-topotypes; they fully agree with the original description and are supplemented here by the first colour pictures of several main somatic features such as a dark brown, characteristically subcylindrical body with long antennae and legs, as well as evident pleurosternal carinae, but faint bulges instead of most of paraterga (Figs 1-4).

Delarthrum furcatum (Golovatch, 1996), comb.n. Figs 5-18.

MATERIAL. $1 \sigma^{7}$ (NMNHS), Nepal, Langtang Valley, Syabrubesi, $1600 \mathrm{~m}, 15.09 .1984$, leg. P. Beron \& S. Andreev; 1 O (ZMUM p2323), Nepal, Betrawati, 600-1000 m a.s.1., 21.07.1981, leg. P. Beron.

REMARKS. This species has been described in the genus Orophosoma Jeekel, 1980, based on a single, holotype $\sigma^{7}$ taken at $2000 \mathrm{~m}$ a.s.l. on Mt Phulchoki, near Kathmandu, Nepal [Golovatch, 1996]. The above new samples derive from two nearby localities and thus may well be regarded as near-topotypes. The main characters are stable, including the shape of paraterga (Figs 5-12), the epi- and hypoproct (Figs 8, 12, 14 \& $15)$, and the sternal lobe between $\sigma^{7}$ coxae 4 , each of these coxae showing a peculiar distoventral tooth (Fig. 16), etc. Whereas the $\sigma^{7}$ from Betrawati agrees with the holotype in virtually every detail (Figs 9-13), the near-topotype from Syabrubesi differs in a slightly larger size, the length being ca $23 \mathrm{~mm}$, the width 2.0 and 2.5 mm on midbody pro- and metazonae, respectively (versus ca $21,1.9$ and $2.3 \mathrm{~mm}$, respectively), while its body is chocolate brown with distally infuscate antennae (Figs 5 \& 6) (versus pale rusty brown to reddish-brown with monochrome antennae). Faint differences are also found in the caudal corner of paraterga being a little more acute, especially from segment 11 (versus 12) whence it starts projecting beak-like behind the rear tergal margin (Figs 5, $7 \& 8$ ). The most important similarities, however, lie in gonopod structure (Figs $10,13,17 \& 18)$, especially the same solenophore, the presence of a long process (s) at the base of the solenomere, and of a deeply bifurcate, dorsal, distofemoral process, but the latter's lateral branch b in the new sample from Syabrubesi is considerably shorter than branch o, not vice versa (cf. Golovatch [1996, figs 6769]). Still these variations are so minor that they certainly fail to question the species' identity.

\section{The status of Delarthrum}

Delarthrum Attems, 1936 has hitherto remained monobasic, with D. obscurum Attems, 1936, from Punjab, Pakistan being the type, and sole, species [Attems, 1936]. Jeekel [1980a] first allocated this genus in the tribe Polydrepanini, putting emphasis on a well-developed and elongate gonopod femorite, versus a strongly abbreviated one observed in Alogolykini, the second constituent tribe of the subfamily Alogolykinae. A little later, however, Jeekel [1980b] reshaped both these tribes and assigned Delarthrum to the Alogolykini on account of an untwisted gonofemorite which retains the seminal groove running on its mesal side alone, versus a strongly twisted, helicoid femorite supporting the seminal groove largely on the lateral side as seen in the Polydrepanini. Both tribes have recently been redefined: a strong, rod-shaped solenomere versus a thin, flagelliform one remains the basic difference between the tribes Alogolykini and Polydrepanini, respectively [Likhitrakarn et al., 2013]. This distinction, however, is often far from clear-cut. For instance, numerous species of Alogolykinae demonstrate slender, but ribbon-shaped solenomeres which are kind of intermediate between really thick and rod-like, on the one hand, and clearly flagelli- or filiform conditions, on the other hand.

The large Himalayan genus Orophosoma Jeekel, 1980 has been reviewed and shown to comprise 17 species, all keyed: O. aberrans Golovatch, 1996, O. alatum Golovatch, 1996, O. bifidum Golovatch, 1996, O. extremum Golovatch, 1996, O. facile Golovatch, 1996, O. fechteri Golovatch, 1990, O. furcatum Golovatch, 1996, O. hingstoni (Carl, 1935) (the type species), O. invocatum Golovatch, 1996, O. longispinum Golovatch, 1996, O. modestum Golovatch, 1996, O. prolixum Golovatch, 1996, O. simplex Golovatch, 1996, O. simulans (Carl, 1935), O. subalatum Golovatch, 1996, O. subsimulans Golovatch, 1996 and O. uncum Golovatch, 1996 [Golovatch, 1996]. On account of gonopod structure alone, initially Orophosoma was not only considered as a member of the Polydrepanini, but also as being especially similar to further two Himalayan species, both described by Attems [1936] and long known as supposedly representing two distinct, but then still unnamed generic categories [Jeekel, 1980a, b]. First Golovatch [1984] partly formalized that hint by proposing Armolites Golovatch, 1984 to solely encompass the type species, Kronopolites spiniger Attems, 1936. Later, Golovatch [1992] erected Martensosoma Golovatch, 1992 as well, but this time not only to incorporate the type species, Kronopolites unicolor Attems, 1936, but also to harbour the newly described M. spiniger Golovatch, 1992, M. schawalleri Golo- 


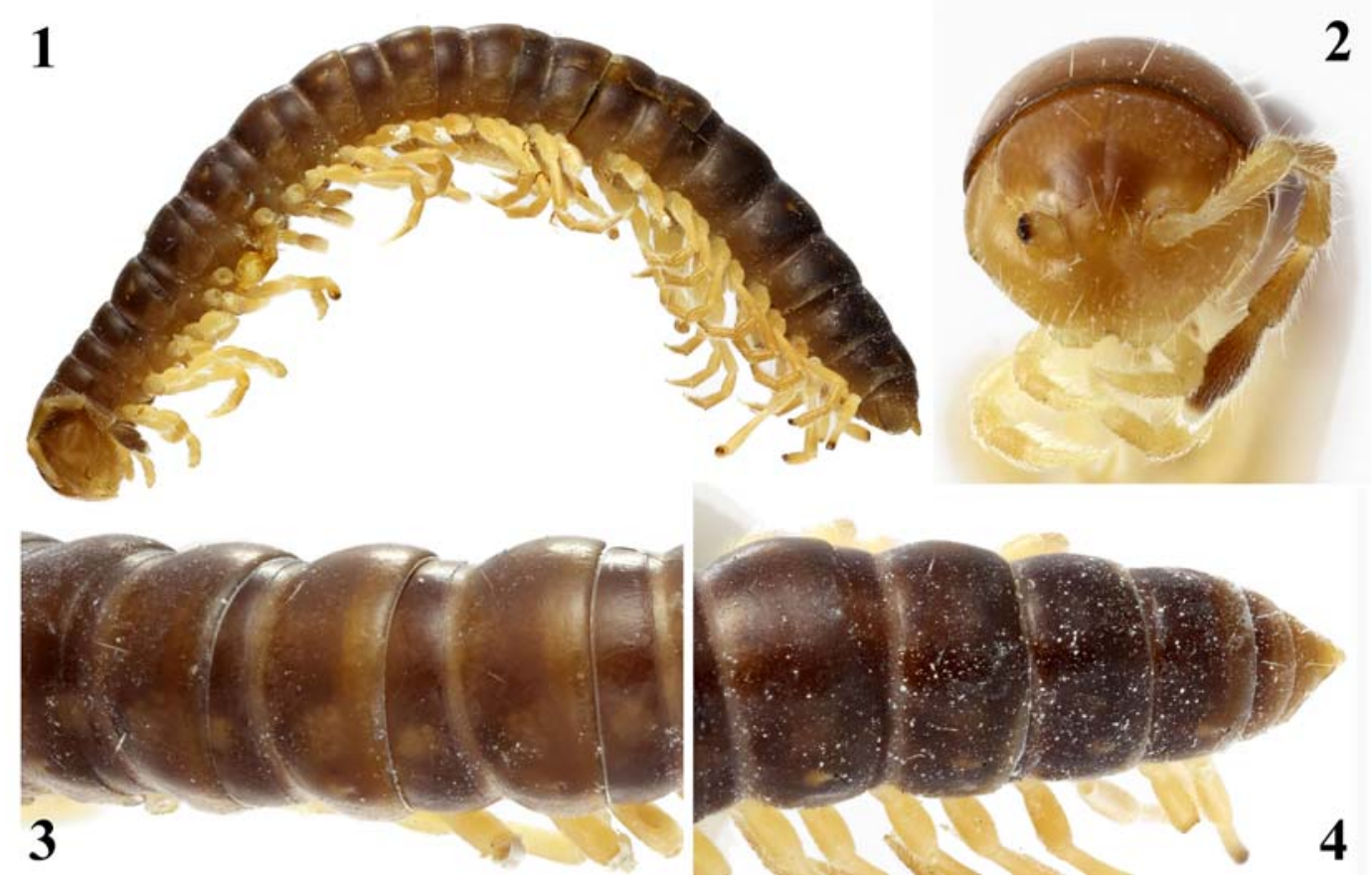

Figs 1-4. Anoplodesmus martensi (Golovatch, 1990), o from Danje Guard Post, 3500-3600 m a.s.1.: 1 — habitus, lateral view; 2 anterior part of body, ventral view; 3 \& 4 - middle and caudal parts of body, respectively, dorsal views. Photos taken by K. Makarov, not to scale.

Рис. 1-4. Anoplodesmus martensi (Golovatch, 1990), о7 из Danje Guard Post, 3500-3600 м н.у.м.: 1 - внешний вид, сбоку; 2 передняя часть тела, снизу; 3, 4 - соответственно средняя и задняя части тела, сверху. Фото сделаны К. Макаровым, без масштаба.

vatch, 1992, M. nyakense Golovatch, 1992, M. elegans Golovatch, 1992, M. foveatum Golovatch, 1992 and M. splendens Golovatch, 1992. Just like Delarthrum, Martensosoma spp. show a rather peculiar, oblique cingulum demarcating skewed solenophore + solenomere, with or without a nearby distogonofemoral process.

Armolites has been defined through the presence of a distal spine/process on the gonopod femorite, coupled with a rather long and flagelliform solenomere. This genus has been believed to contain four species, all keyed: A. spiniger (Attems, 1936), A. communicans Golovatch, 1992, A. similis Golovatch, 1992 and A. chulingensis Golovatch, 1994 [Golovatch, 1994]. Martensosoma has been slightly redefined, based on a slender, but flattened solenomere as opposed to a subflagelliform one in Orophosoma spp., with formal transfers of both $M$. nyakense Golovatch, 1992 and $M$. spiniger Golovatch, 1992 elsewhere, and a description of M. silvestre Golovatch, 1994; a key to all six recognized species of that genus has also been compiled [Golovatch, 1994].

Even though Nepalomorpha Golovatch, 1994 and Parorthomorpha Golovatch, 1994 have originally been assigned to the tribe Orthomorphini, Paradoxosomatinae [Golovatch, 1994], neither actually shows the solenophore consisting of a clear-cut lamina medialis and a lamina lateralis that would start parabasally as typically is the case in Orthomorphini. Among other things, these two Himalayan genera also share adenostyles often present on $\sigma^{\gamma}$ femora 1 (these adenostyles being totally uncharacteristic of Orthomorphini!), a very long gonopod coxa, an elongated, suberect, untwisted and simple femorite, a rather simple, lobular and twisted solenophore, and a short, slender, largely ribbon-shaped solenomere which is usually shorter than the solenophore. The sole distinction lies in the solenophore in Nepalomorpha being clearly elongate and slenderer, whereas in Parorthomorpha it is stouter. Nepalomorpha contains only four nominate species: $N$. arunensis Golovatch, 1994, N. hirsuta Golovatch, 1994, N. kuznetsovi Golovatch, 1994 (the type species) and N. spinigera (Golovatch, 1992), all keyed, while Parorthomorpha counts nine species: P. affinis Golovatch, 1994, P. granulosa Golovatch, 1994, P. intermedia Golovatch, 1994, P. longiseta Golovatch, 1994 (the type species), P. nyakensis (Golovatch, 1992), P. philosophica Golovatch, 1994, P. spectabilis Golovatch, 1994, P. tergalis Golovatch, 1994 and P. tuberculata Golovatch, 1994, all keyed as well [Golovatch, 1994]. The species $P$. panda Golovatch, 2009, described more recently from Shaanxi, north-central China [Golovatch, 2009], is clearly distinct in a subflagelliform and rather long solenomere traversing distally both apical lobes/ laminae of the solenophore. However, based also on a strongly oblique cingulum demarcating the solenophore, $P$. panda so readily resembles Polylobosoma Jeekel, 

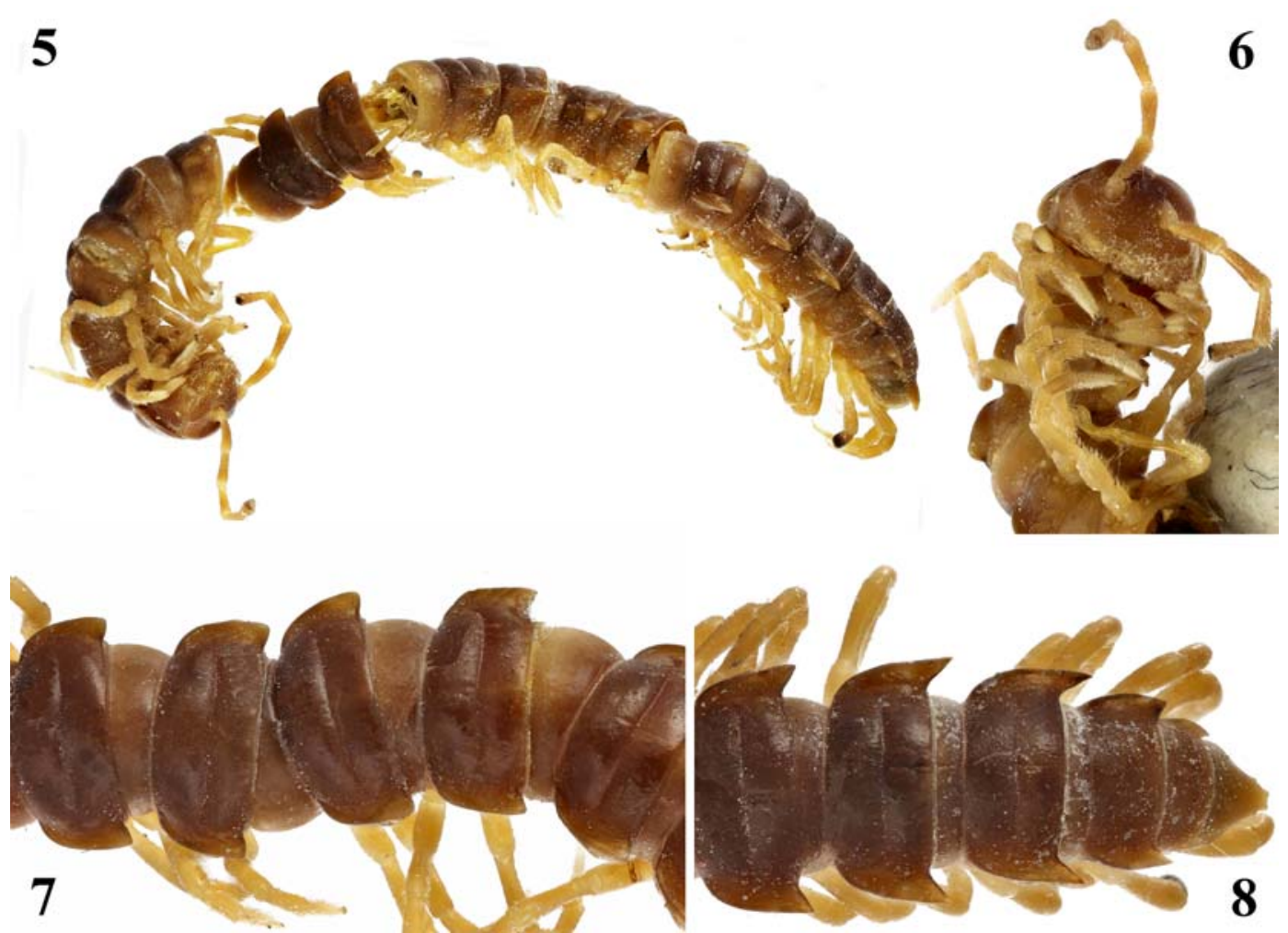

Figs 5-8. Delarthrum furcatum (Golovatch, 1996), o7 from Syabrubesi: 5 - habitus, lateral view; 6 - anterior part of body, ventral view; $7 \& 8$ - middle and caudal parts of body, respectively, dorsal views. Photos taken by K. Makarov, not to scale.

Рис. 5-8. Delarthrum furcatum (Golovatch, 1996), О7 из Syabrubesi: 5 - внешний вид, сбоку; 6 - передняя часть тела, снизу; 7, 8 - соответственно средняя и задняя части тела, сверху. Фото сделаны К. Макаровым, без масштаба.
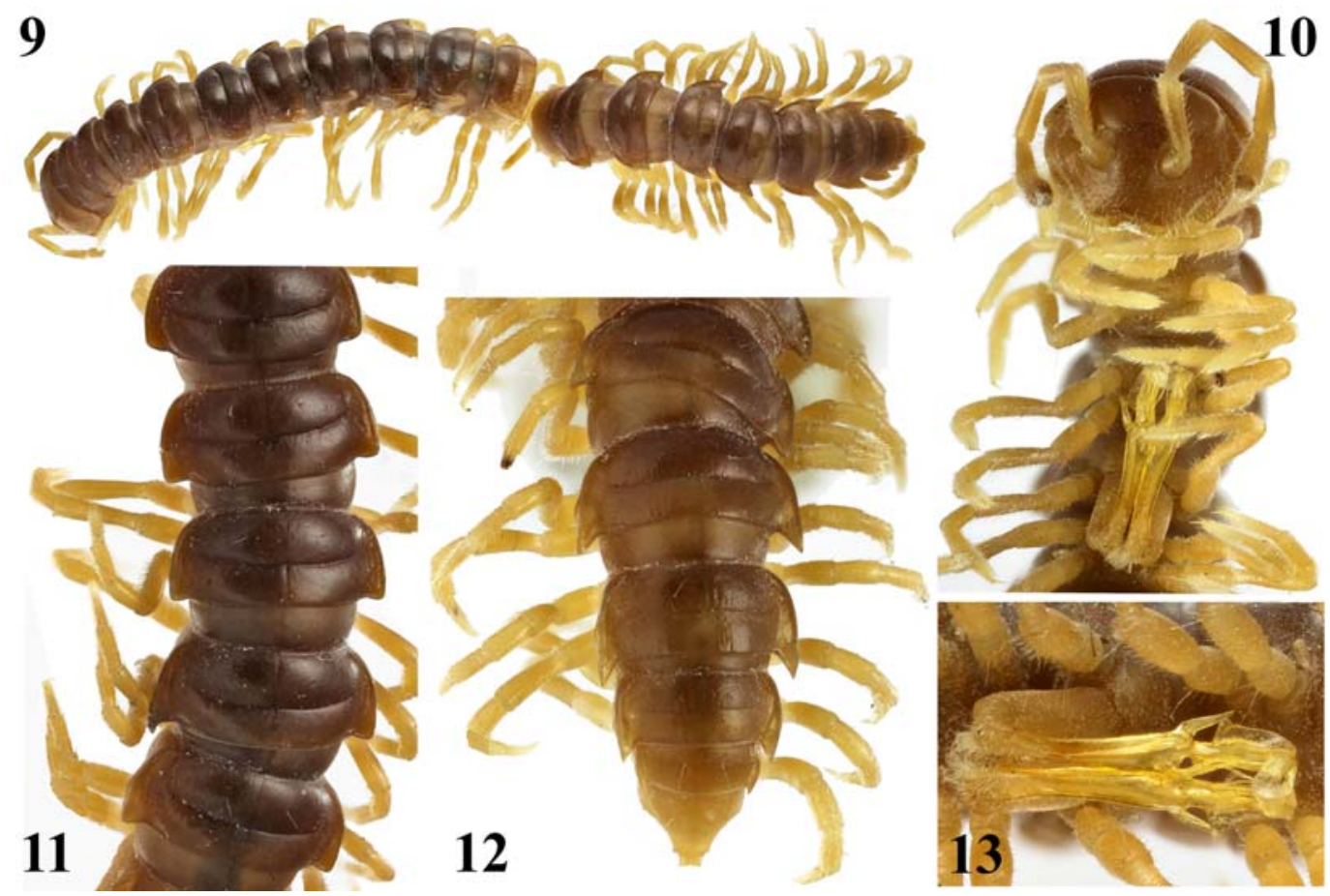

Figs 9-13. Delarthrum furcatum (Golovatch, 1996), O from Betrawati: 9 - habitus, lateral view; 10 — anterior part of body, ventral view; 11 \& 12 - middle and caudal parts of body, respectively, dorsal views; 13 - gonopods, ventral view. Photos taken by K. Makarov, not to scale.

Рис. 9-13. Delarthrum furcatum (Golovatch, 1996), О7 из Betrawati: 9 - внешний вид, сбоку; 10 - передняя часть тела, снизу; 11,12 - соответственно средняя и задняя части тела, сверху; 13 - гоноподы, снизу. Фото сделаны К. Макаровым, без масштаба. 


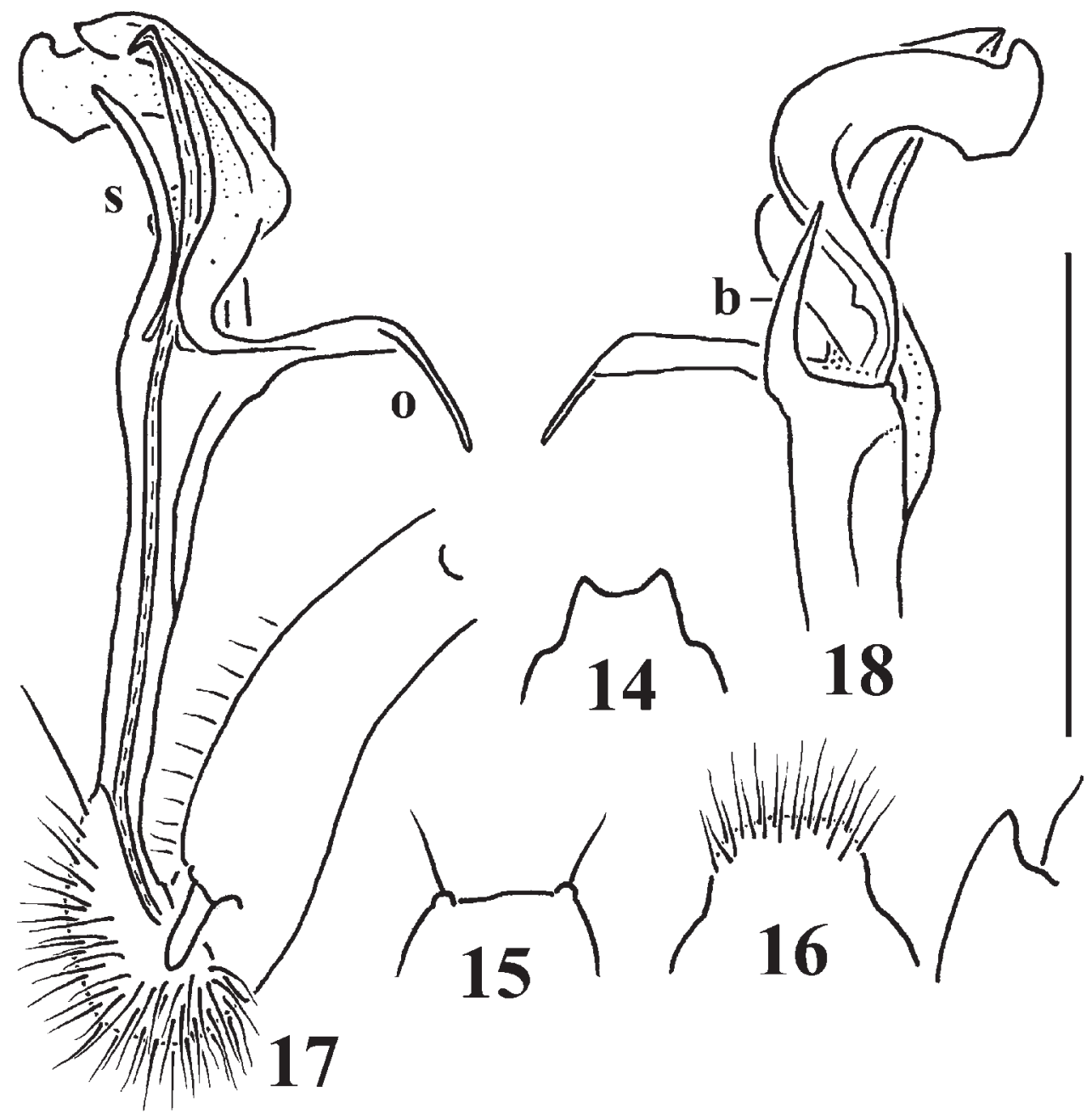

Figs 14-18. Delarthrum furcatum (Golovatch, 1996), ○’ from Syabrubesi: 14 — epiproct tip, dorsal view; 15 - hypoproct, ventral view; 16 - sternal lobe between coxae 4 and mesal part of right coxa 4, caudoventral view; 17 - right gonopod, mesal view; 18 - distal half of right gonopod, lateral view. Scale bar: $1.0 \mathrm{~mm}$.

Рис. 14-18. Delarthrum furcatum (Golovatch, 1996), О7 из Syabrubesi: 14 - кончик эпипрокта, сверху; 15 - гипопрокт, снизу; 16 - стернальная пластинка между тазиками 4 и внутренная часть правого тазика 4, одновременно сзади и снизу; 17 правый гонопод, изнутри; 18 - дистальная половина правого гонопода, сбоку. Масштаб 1,0 мм.

1980, with two species from China and Vietnam [Jeekel, 1980a], that the following formal transfer is proposed: Polylobosoma panda (Golovatch, 2009), comb.n. ex Parorthomorpha.

Considering the profound range of variation demonstrated by nominate Orophosoma species alone [Golovatch, 1996], the above generic distinctions seem to be too weak to hold, because their main somatic and, especially, gonopod characters are basically the same, with all possible transitions involved. As a result, the following new synonymies are advanced: Nepalomorpha Golovatch, 1994, = Parorthomorpha Golovatch, 1994, = Martensosoma Golovatch, 1992, = Armolites Golovatch, 1984, = Orophosoma Jeekel, 1980, = Delarthrum Attems, 1936, all syn.n., with the following 40 new formal transfers: D. arunense (Golovatch, 1994), D. hirsutum (Golovatch, 1994), D. kuznetsovi (Golo- vatch, 1994) and D. spinigerum (Golovatch, 1992), all comb.n. ex Nepalomorpha; D. affine (Golovatch, 1994), D. granulosum (Golovatch, 1994), D. intermedium (Golovatch, 1994), D. longisetum (Golovatch, 1994), D. nyakense (Golovatch, 1992), D. philosophicum (Golovatch, 1994), D. spectabile (Golovatch, 1994), D. tergale (Golovatch, 1994) and D. tuberculatum (Golovatch, 1994), all comb.n. ex Parorthomorpha; D. elegans (Golovatch, 1992), D. foveatum (Golovatch, 1992), D. schawalleri (Golovatch, 1992), D. silvestre (Golovatch, 1994), D. splendens (Golovatch, 1992) and D. unicolor (Attems, 1936), all comb.n. ex Martensosoma; D. chulingense (Golovatch, 1994), D. communicans (Golovatch, 1992), D. simile (Golovatch, 1992) and D. spiniger (Attems, 1936), all comb.n. ex Armolites; D. aberrans (Golovatch, 1996), D. alatum (Golovatch, 1996), D. bifidum (Golovatch, 1996), D. 
extremum (Golovatch, 1996), D. facile (Golovatch, 1996), D. fechteri (Golovatch, 1990), D. furcatum (Golovatch, 1996), D. hingstoni (Carl, 1935), D. invocatum (Golovatch, 1996), D. longispinum (Golovatch, 1996), D. modestum (Golovatch, 1996), D. prolixum (Golovatch, 1996), D. simplex (Golovatch, 1996), D. simulans (Carl, 1935), D. subalatum (Golovatch, 1996), D. subsimulans (Golovatch, 1996) and D. uncum (Golovatch, 1996), all comb.n. ex Orophosoma. Furthermore, because of homonymy, D. spiniger (Golovatch, 1992) is to be renamed, the easiest option, following the earlier transfer of that species to Nepalomorpha by Golovatch [1994], being D. spinigerum (Golovatch, 1992), nom.n.

As a result, the genus currently contains 48 species, including seven new congeners described below. It can be rediagnosed as follows.

\section{Delarthrum Attems, 1936}

DIAGNOSIS. Small- to large-sized Polydrepanini (ca 1-4 cm long) with 20 segments, paraterga from poorly to strongly developed, midbody metaterga only rarely markedly setose, usually nearly or fully bare; paraterga 5 occasionally conspicuously enlarged; a lobe between $\sigma^{7}$ coxae 4 always evident, an adenostyle on $\sigma^{7}$ femur 1 and $\sigma^{7}$ tarsal brushes often present.

Gonopod coxa subcylindrical, long, usually nearly as long as femorite, densely setose distolaterally. Prefemoral (= densely setose) portion short, only rarely with a lateral process, typically $1 / 3$ to $1 / 2$ as long as an elongate, slender, suberect, only sometimes distally subclavate femorite; the latter not twisted (= seminal groove running entirely on mesal side), largely simple, devoid both of a mesal gutter and a postfemoral sulcus, distally only rarely either with a single process, sometimes biramous, or even with two processes, set off terminally by a distinct, typically oblique sulcus or cingulum to demarcate a simple to complex, lamellar, mainly obviously twisted solenophore, this latter normally being devoid of a clearly folded lamina lateralis and, especially, of a lamina medialis; a free solenomere typically starting a little proximal to sulcus/cingulum, only rarely flagelliform and up to as long as solenophore, usually slender, flattened, ribbon-shaped, short, fully to largely exposed, suberect or curved, straight or twisted, only rarely with outgrowths, these always being minor at most, invariably tightly applied to mesal face and guided/supported by folds and lobes, but never traversing apical parts, of a generally laterally lying solenophore.

Type species: Delarthrum obscurum Attems, 1936, by original designation.

Since the existing keys to ex-Nepalomorpha, exParorthomorpha, ex-Martensosoma, ex-Armolites and
ex-Orophosoma species are available and still valid [Golovatch, 1992, 1994 1996], the diagnoses of the new congeners described below may be quite concise. Nor does a general key to Delarthrum spp. seem to be necessary.

\section{Descriptions of new species}

\section{Delarthrum beroni sp.n.}

Figs 19-41.

HOLOTYPE $0^{7}$ (NMNHS), Nepal, Pokhara, 900 m, 3.07.1981, leg. P. Beron.

PARATYPES: $10^{7}$ (NMNHS), Nepal, Tansen, Lumbini Zone,

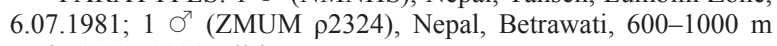
a.s.1., 21.07.1981, all leg. P. Beron.

NAME. Honours Petar Beron, my good friend and an outstanding Bulgarian zoologist who collected this and many other diplopods across the world.

DIAGNOSIS. Being a typical ex-Martensosoma, this new species keys out as Delarthrum splendens (Golovatch, 1992) (see Golovatch [1994] and also above), but is readily distinguishable by a slightly different shape of the solenophore and caudally subacuminate paraterga.

DESCRIPTION. Length of adults ca 22 (holotype) or $23 \mathrm{~mm}$ (paratype), width of midbody pro- and metazonae 1.8 and 2.0 (holotype) or 1.9 and $2.1 \mathrm{~mm}$ (paratype), respectively. Coloration in alcohol uniformly dark chocolate brown (Figs 19-26); antennae light brown, somewhat infuscate distally, but tip whitish; front and lateral parts of head light brown; tip of epiproct and legs light yellow-brown, but legs slightly infuscate distally.

Body submoniliform. In width, head $=$ segment 2 $=3<$ collum $=4<5-16$; thereafter body very gently tapering. Clypeolabral region and frons densely setose, vertigial region with a few setae only. Antennae rather short and subfiliform (Figs 19, 20, 23 \& 24), extending back until about midlength of segment 2 when stretched dorsally $\left(O^{7}\right)$; in length, antennomere $2=6>3 \geq 4=5>1=7$. Paraterga very poorly developed (Figs 19-27, 33 \& 34); a small, ventrolateral, caudally rounded, rimmed lobe produced behind tergal margin in collum; a small, rather thin, lowlying crest with a distinct rounded lappet also produced behind tergal margin in segment 2; thereafter small lateral ridges mostly only reaching the rear tergal margin, slightly produced behind it and subspiniform only in segments 3 and 4, as well as 12-19; paraterga set low, largely lying at about half of midbody height; calluses very narrow in dorsal view, but in lateral view thin in poreless segments and clearly higher/thicker in pore-bearing ones, delimited by a deep sulcus both dorsally and, only in caudal $1 / 4$ (poreless segments) to $1 / 3$ extent (pore-bearing seg-

Figs 23-26. Delarthrum beroni sp.n., paratype from Lumbini Zone: 23 - habitus, lateral view; 24 - anterior part of body, ventral view; 25 \& 26 - middle and caudal parts of body, respectively, dorsal views. Photos taken by K. Makarov, not to scale.

Рис. 23-26. Delarthrum beroni sp.n., паратип из Lumbini Zone: 23 - внешний вид, сбоку; 24 - передняя часть тела, снизу; 25 , 26 - соответственно средняя и задняя части тела, сверху. Фото сделаны К. Макаровым, без масштаба. 


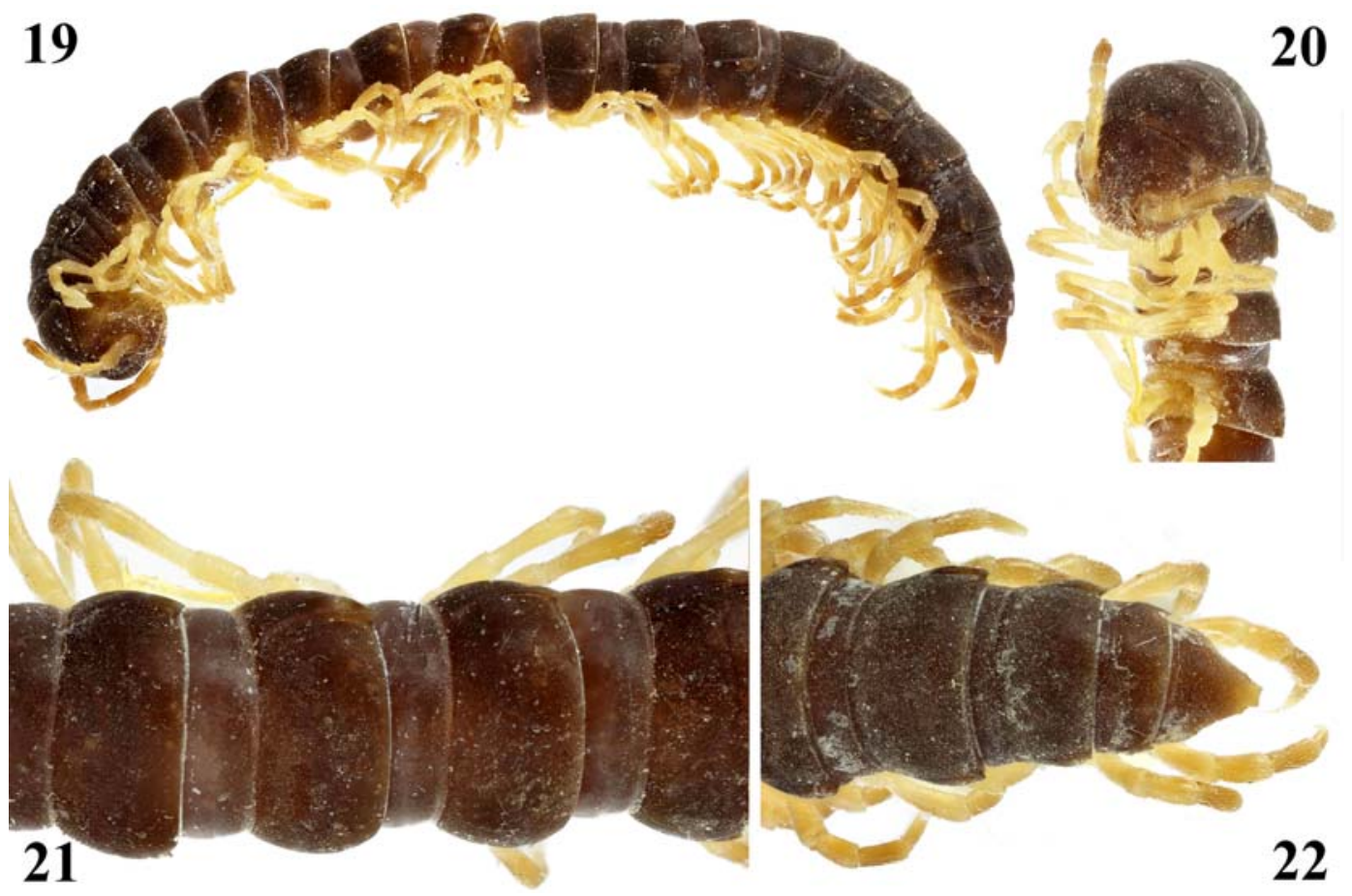

Figs 19-22. Delarthrum beroni sp.n., holotype: 19 - habitus, lateral view; 20 - anterior part of body, ventral view; $21 \& 22-$ middle and caudal parts of body, respectively, dorsal views. Photos taken by K. Makarov, not to scale.

Рис. 19-22. Delarthrum beroni sp.n., голотип: 19 - внешний вид, сбоку; 20 - передняя часть тела, снизу; 21, $22-$ соответственно средняя и задняя части тела, сверху. Фото сделаны К. Макаровым, без масштаба.

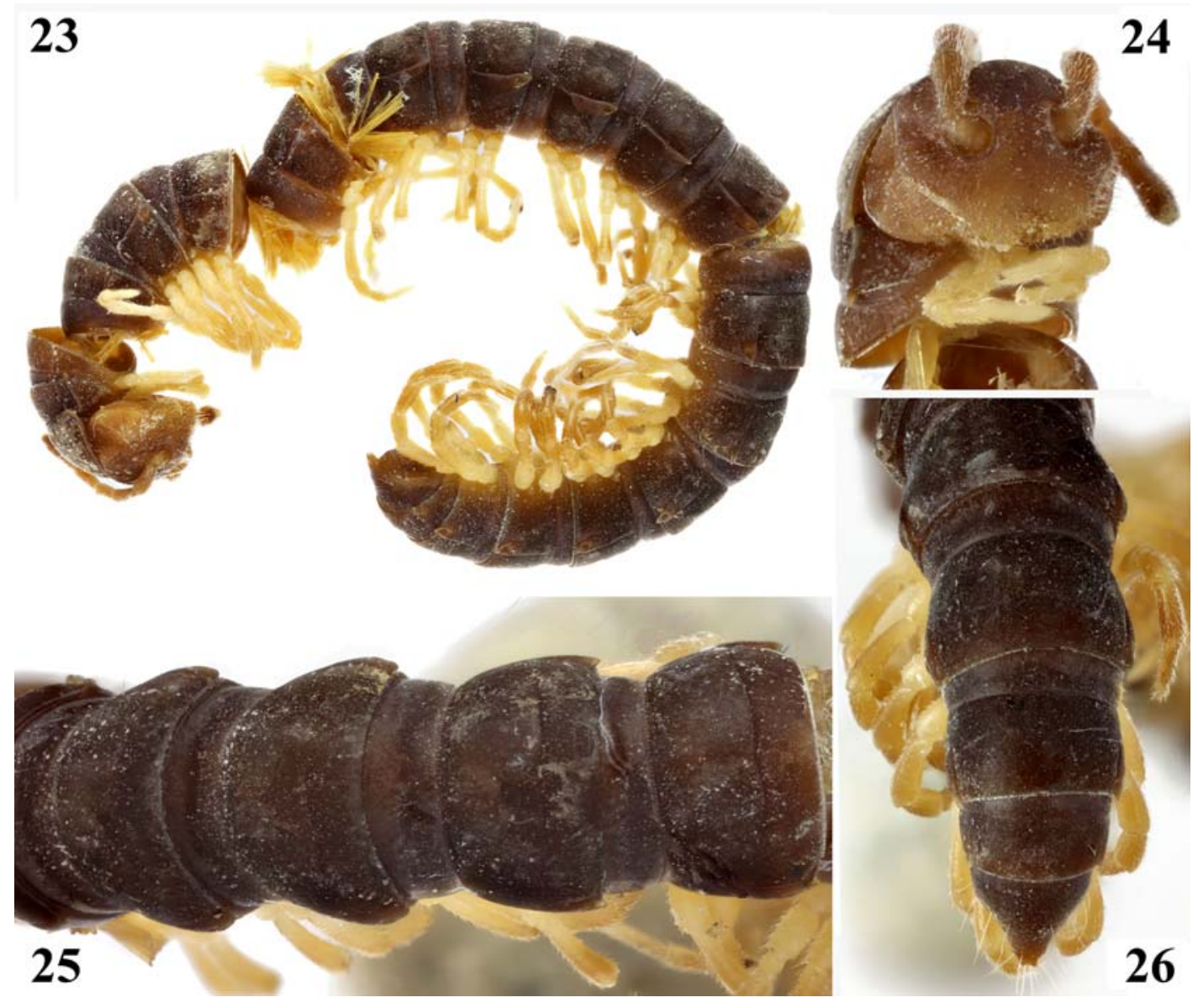



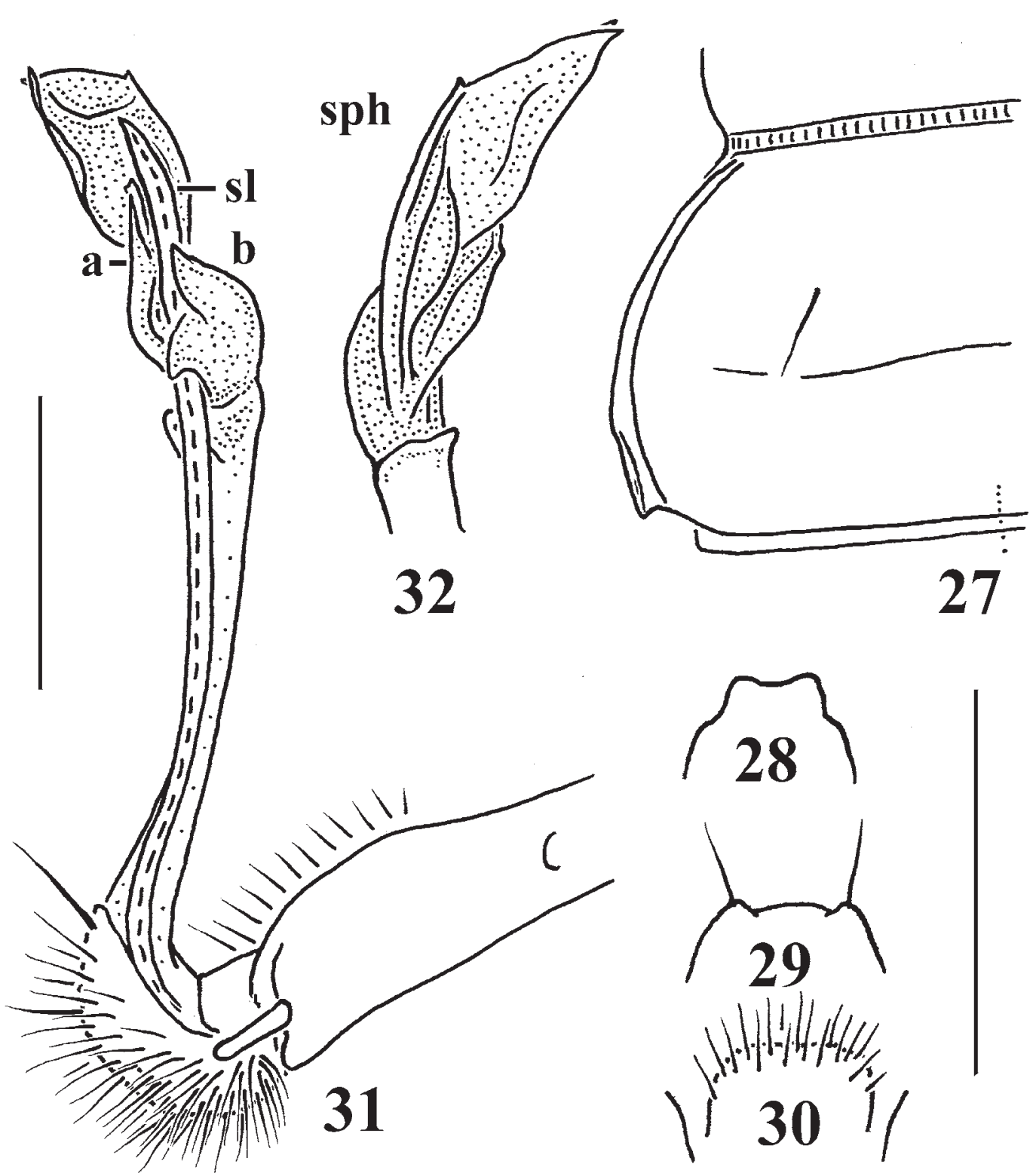

Figs 27-32. Delarthrum beroni sp.n., holotype: 27 - left half of segment 10, dorsal view; 28 - epiproct tip, dorsal view; 29 hypoproct, ventral view; 30 - sternal lobe between coxae 4, caudoventral view; 31 - right gonopod, mesal view; 32 - distal half of right gonopod, lateral view. Scale bar: $1.0(27-30)$ and $0.5 \mathrm{~mm}(31 \& 32)$.

Рис. 27-32. Delarthrum beroni sp.n., голотип: 27 - левая половина сегмента 10, сверху; 28 — кончик эпипрокта, сверху; 29 гипопрокт, снизу; 30 - стернальная пластинка между тазиками 4, одновременно сзади и снизу; 31 - правый гонопод, изнутри; 32 - дистальная половина правого гонопода, сбоку. Масштаб 1,0 (27-30) и 0,5 мм (31 и 32).

ments), ventrally, these sulci growing increasingly obliterate towards telson; paraterga 19 scarcely traceable. Ozopores lateral, invisible from above, lying inside an evident ovoid groove at ca $1 / 4-1 / 5$ of metatergal length in front of caudal margin (Figs 19, 23 \& 34). Body surface smooth and rather clearly shining throughout. Axial line missing. Transverse sulcus a thin line increasingly poorly visible on metaterga $5-18$, far from reaching bases of paraterga, absent from $19^{\text {th }}$. Tergal setae medium-sized (ca 1/3-1/4 of metatergal length), mostly abraded, setation pattern only sometimes traceable due to vague insertion points, on collum arranged probably in three transverse rows (likely ?4+4, $2+2$ and $? 3+3$ ), on following segments only sometimes retained in a single transverse row of probably $3+3$ setae in front $1 / 3$ of metaterga, but pattern traceable at least as $3+3$ before and $4+4$ behind sulcus, discarding a marginal seta or, usually, insertion point lying in front $1 / 4$ of paratergum 2 or at about midway on following paraterga. Stricture dividing pro- and metazonae rather narrow, deep, finely ribbed down to level of paraterga (Figs 21, 22, 25-27, 33 \& 34). Pleurosternal carinae wanting. Epiproct (Figs 22, 26, 28 \& 35) short, barely concave, subapical lateral papillae small. Hypoproct 


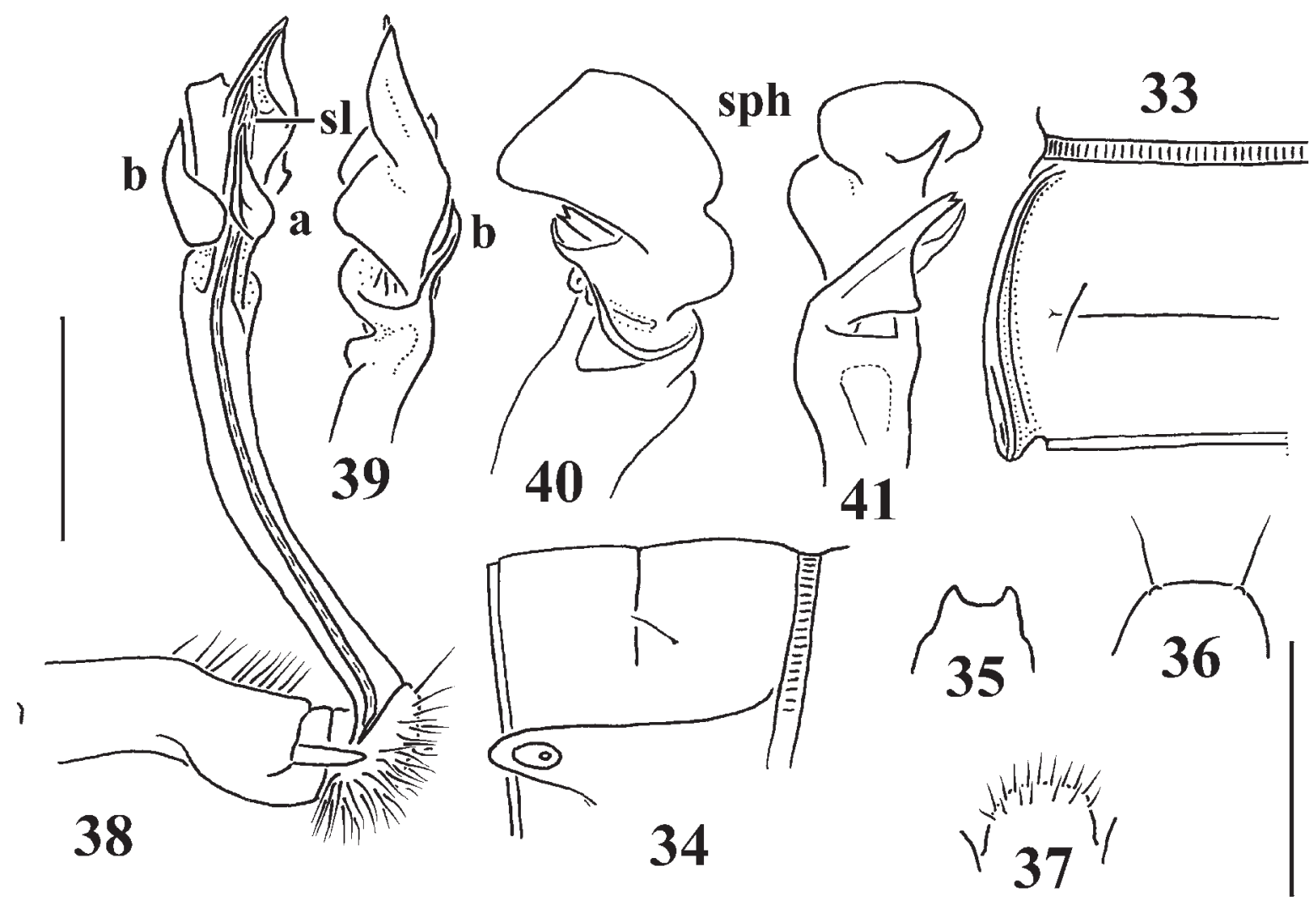

Figs 33-41. Delarthrum beroni sp.n., paratype from Lumbini Zone: 33 - left half of segment 10, dorsal view; 34 - right half of segment 10, lateral view; 35 - epiproct tip, dorsal view; 36 - hypoproct, ventral view; 37 - sternal lobe between coxae 4, caudoventral view; 38 - left gonopod, mesal view; 39-41 — distal half of left gonopod, lateral, ventral and dorsal views, respectively. Scale bar: 1.0 (33-37) and $0.5 \mathrm{~mm}(38-41)$.

Рис. 33-41. Delarthrum beroni sp.n., паратип из Lumbini Zone: 33 - левая половина сегмента 10, сверху; 34 - правая половина сегмента 10, сбоку; 35 - кончик эпипрокта, сверху; 36 - гипопрокт, снизу; 37 - стернальная пластинка между тазиками 4, одновременно сзади и снизу; 38 - левый гонопод, изнутри; 39-41 - дистальная половина левого гонопода, соответственно сбоку, снизу и сверху. Масштаб 1,0 (33-37) и 0,5 мм (38-41).

(Figs 29 \& 36) subtrapeziform, caudal $1+1$ setae clearly separated, borne on small marginal knobs.

Sternites without modifications, sparsely setose, cross-impressions evident; a rather high, linguiform, subquadrate, setose lobe between coxae 4 (Figs $30 \&$ 37). Legs long, obviously crassate and ca 1.6-1.7 times as long as midbody height $\left(\sigma^{7}\right)$ (Figs 19, 20 \& 23); prefemora rather slender, not swollen laterally; femur 1 without adenostyle; tarsal brushes gradually thinning out towards last five leg-pairs.

Gonopods (Figs 31, 32 \& 38-41) fairly complex; coxite long and slender, subcylindrical, setose distolaterally; prefemoral part as usual, densely setose, short, between ca $1 / 3$ and $1 / 2$ the length of femorite; the latter simple, very slender, suberect, only very faintly curved and enlarged distad, with neither evidence of torsion (= seminal groove running entirely on mesal side) nor any outgrowths, set off from acropodite (= solenomere and solenophore) by a clearcut cingulum. Solenophore (sph) particularly complex, lamellar, about half as long as femorite, twisted, slightly longer than a rather thick, short and suberect solenomere (sl), sheathing the latter through two spinigerous folds on mesal side (a \& b).

\section{Delarthrum typicum sp.n.}

Figs 42-52.

HOLOTYPE $O^{7}$ (NMNHS), Nepal, Langtang National Park, Danje Guard Post, 3100 m, 19.07.1981, leg. P. Beron.

PARATYPE: 1 ( NMNHS), same locality, together with holotype.

NAME. To emphasize the typical ex-Orophosoma facies of this new species, including the presence of a distodorsal tooth on the gonopod femorite.

DIAGNOSIS. Being a typical ex-Orophosoma, this new species keys out as D. invocatum (Golovatch, 1996) (see Golovatch [1996] and also above), but differs readily by a considerably smaller adenostyle on $\sigma^{7}$ femur 1, an acuminate apical lobe of the solenophore and even more prominent paraterga.

DESCRIPTION. Length of adults ca 30 (holotype) or $33 \mathrm{~mm}$ (paratype), width of midbody pro- and metazonae 2.3 and 3.8 (holotype) or 3.5 and $4.0 \mathrm{~mm}$ (paratype), respectively. Coloration in alcohol uniformly 

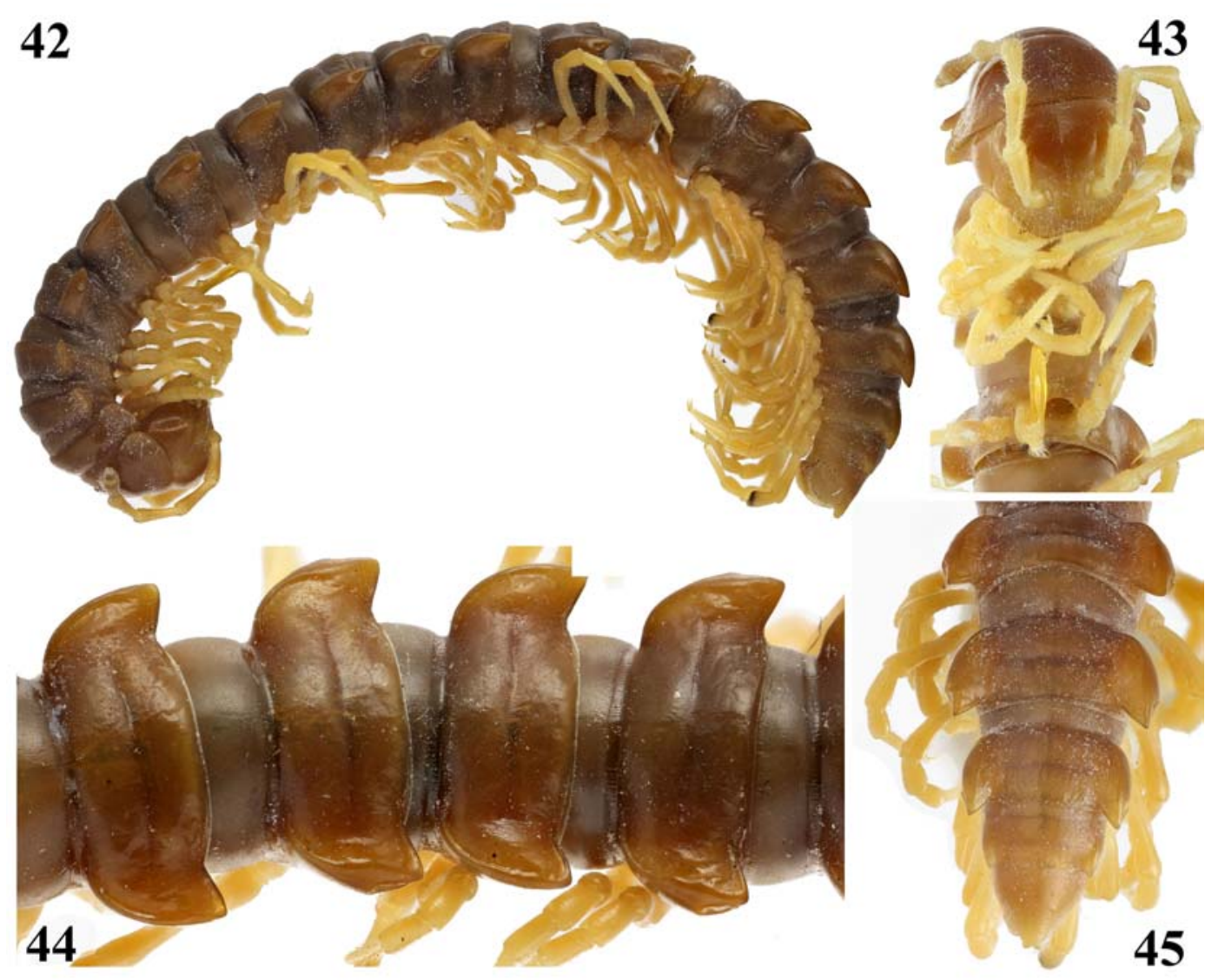

Figs 42-45. Delarthrum typicum sp.n., holotype: 42 - habitus, lateral view; 43 - anterior part of body, ventral view; 44 \& 45 middle and caudal parts of body, respectively, dorsal views. Photos taken by K. Makarov, not to scale.

Рис. 42-45. Delarthrum typicum sp.n., голотип: 42 - внешний вид, сбоку; 43 - передняя часть тела, снизу; 44 и 45 соответственно средняя и задняя части тела, сверху. Фото сделаны К. Макаровым, без масштаба.

dark ochraceous brown (Figs 42-45); antennae light yellow-brown, but infuscate light brown distally, except for a whitish tip; legs, venter and tip of epiproct light yellow-brown.

In width, head $<$ segment $2<$ collum $<3<4<5$ 16 ; thereafter body very gently tapering. Clypeolabral region and frons rather sparsely setose, front half of vertigial region with $1+1$ setae. Antennae rather medium-sized and slightly clavate (Figs $42 \& 43$ ), extending behind until midway of segment $3\left(\sigma^{7}\right)$ or behind segment $2(+)$ when stretched dorsally; in length, antennomere $2>3=5>6>1=7$. Paraterga strongly developed (Figs 42-45); a large, ventrolateral, rimmed, broadly and regularly rounded lobe not produced behind tergal margin in collum; a small, rather thin, lowlying crest with two rounded lappets, one produced forward, the other behind tergal margin in segment 2; thereafter paraterga 3, 4 and 9-19 $\left(\sigma^{1}\right)$ or 3 and 16-19 (†) keel-shaped and also drawn behind rear tergal contour; in lateral view, paraterga narrow (poreless segments) or thicker (pore-bearing segments), increasingly subspiniform, narrowly rounded to nearly pointed and beak-shaped in segments 13-19 $\left(\mathrm{O}^{7}\right)$ or 15-19 (); paraterga set low, largely lying at about upper $1 / 3$ of midbody height; calluses narrow rims in dorsal view, regularly rounded in poreless segments, but clearly broader and extended in a midway triangle in front of ozopore, delimited by a deep sulcus both dorsally and, only in caudal $1 / 4$ and only in pore-bearing segments, ventrally; paraterga 19 particularly small, but evident (Fig. 45). Ozopores lateral, invisible from above, lying inside an ovoid groove at about $1 / 4-1 / 5$ of metatergal length in front of caudal margin (Fig. 42). Body tegument smooth and shining, metaterga only in places faintly rugulose, surface below paraterga microgranulate. Axial line nearly missing, very faint at most. Transverse sulcus a deep line clearly visible on metaterga 518 , reaching bases of paraterga, incomplete and poorly developed only on $19^{\text {th }}$. Tergal setae fully abraded, setation pattern untraceable. Stricture dividing pro- and metazonae rather deep and narrow, finely striolate down to level of paraterga (Fig. 44). Pleurosternal carinae wanting. Epiproct (Figs 45 \& 48) short, barely concave, subapical lateral papillae small. Hypoproct (Fig. 49) roundly subtrapeziform, caudal $1+1$ setae clearly separated, not borne on knobs. 


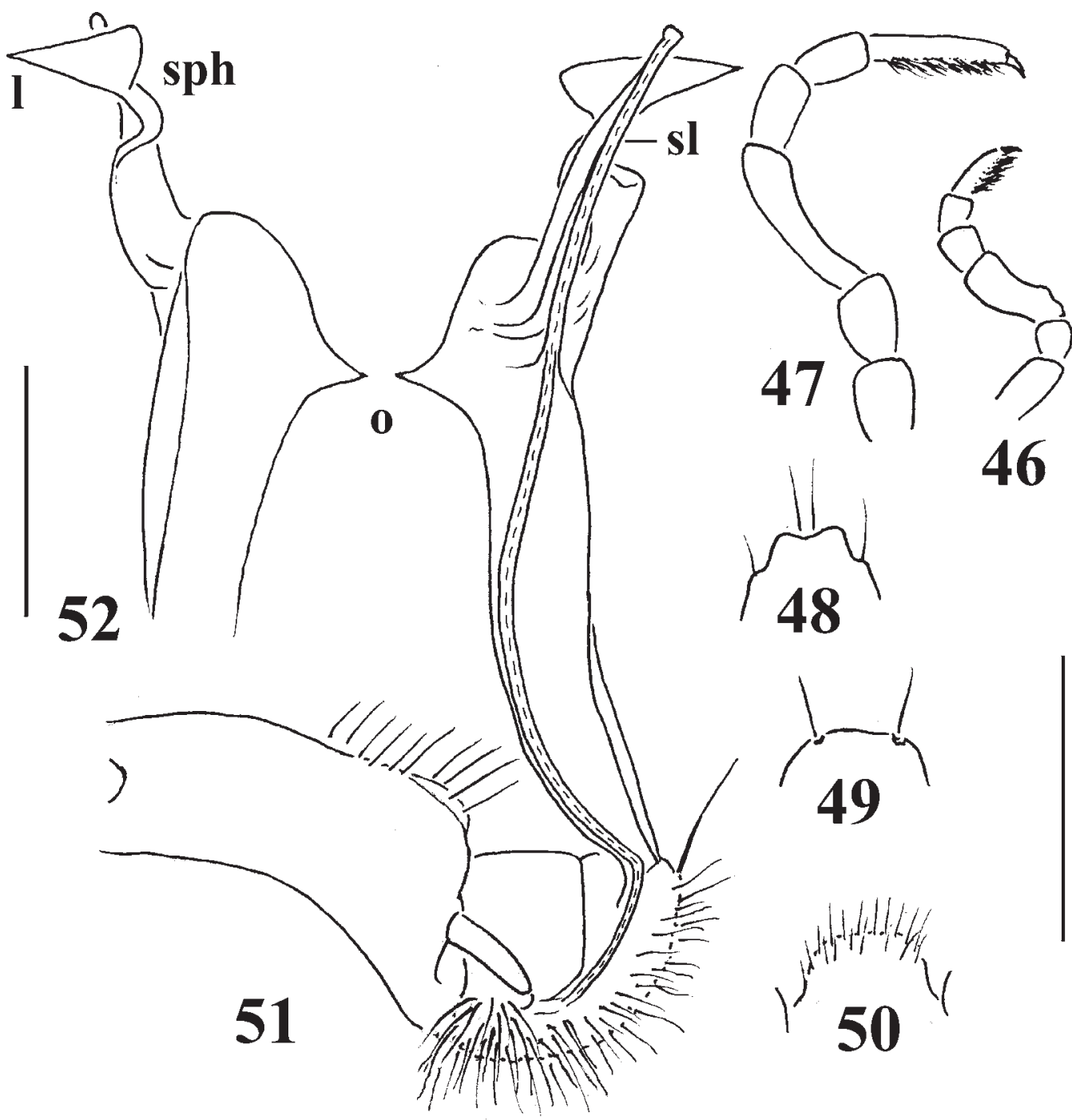

Figs 46-52. Delarthrum typicum sp.n., holotype: 46 - leg 1, lateral view; 47 - leg 7, lateral view; 48 - epiproct tip, dorsal view; 49 - hypoproct, ventral view; 50 - sternal lobe between coxae 4, caudoventral view; 51 - left gonopod, mesal view; 52 - distal half of left gonopod, lateral view. Scale bar: 2.0 (46 \& 47), 1.0 (48-50) and $0.5 \mathrm{~mm}(51 \& 52)$.

Рис. 46-52. Delarthrum typicum sp.n., голотип: 46 - нога 1, сбоку; 47 - нога 7, сбоку; 48 - кончик эпипрокта, сверху; $49-$ гипопрокт, снизу; 50 - стернальная пластинка между тазиками 4, одновременно сзади и снизу; 51 - левый гонопод, изнутри; 52 - дистальная половина левого гонопода, сбоку. Масштаб 2,0 (46 и 47), 1,0 (48-50) и 0,5 мм (51 и 52).

Sternites without modifications, sparsely setose, crossimpressions evident; a rather high, linguiform, subquadrate, setose lobe between $\sigma^{7}$ coxae 4 (Fig. 50). Legs long, ca 1.6-1.7 $\left(\mathrm{O}^{\top}\right)$ or 1.1-1.2 times $(+)$ as long as midbody height; in $O^{7}$ obviously crassate (Figs $42,43 \& 47$ ), prefemora rather slender, not swollen laterally; $\sigma^{\gamma}$ femur 1 (Fig. 46) with a small adenostyle ventroparabasally; tarsal brushes gradually thinning out until $\sigma^{7}$ legs 10 (Fig. 47).

Gonopods (Figs 43, 51 \& 52) rather simple; coxite long and slender, subcylindrical, densely setose distolaterally; prefemoral part as usual, densely setose, short, ca $1 / 2$ as long as femorite; the latter simple, slender, suberect, only slightly enlarged distad, without evidence of torsion, but with a distinct distodorsal tooth (o), set off from acropodite (= solenomere and solenophore) by a clear-cut and oblique cingulum. Solenophore (sph) relatively simple, about half as long as femorite, lamellar, twisted, with a subtriangular, distally acuminate, apical lobe (I), nearly as long as a rather thick, short and suberect solenomere (sl), supporting the latter on mesal side alone.

\section{Delarthrum curtum sp.n.}

Figs 53-63.

HOLOTYPE $\sigma^{7}$ (NMNHS), Nepal, Betrawati, 600-1000 m a.s.1., 21.07.1981, leg. P. Beron.

PARATYPES: 1 \% (NMNHS), same data, together with holotype; $1 O^{\top}$ (strongly fragmented) (NMNHS), Nepal, Langtang Valley, 09.1984, leg. P. Beron.

NAME. To emphasize the short solenophore and solenomere.

DIAGNOSIS. Being a typical ex-Parorthomorpha, this new species keys out as D. intermedium (Golovatch, 1994) (see Golovatch [1994] and also above), 


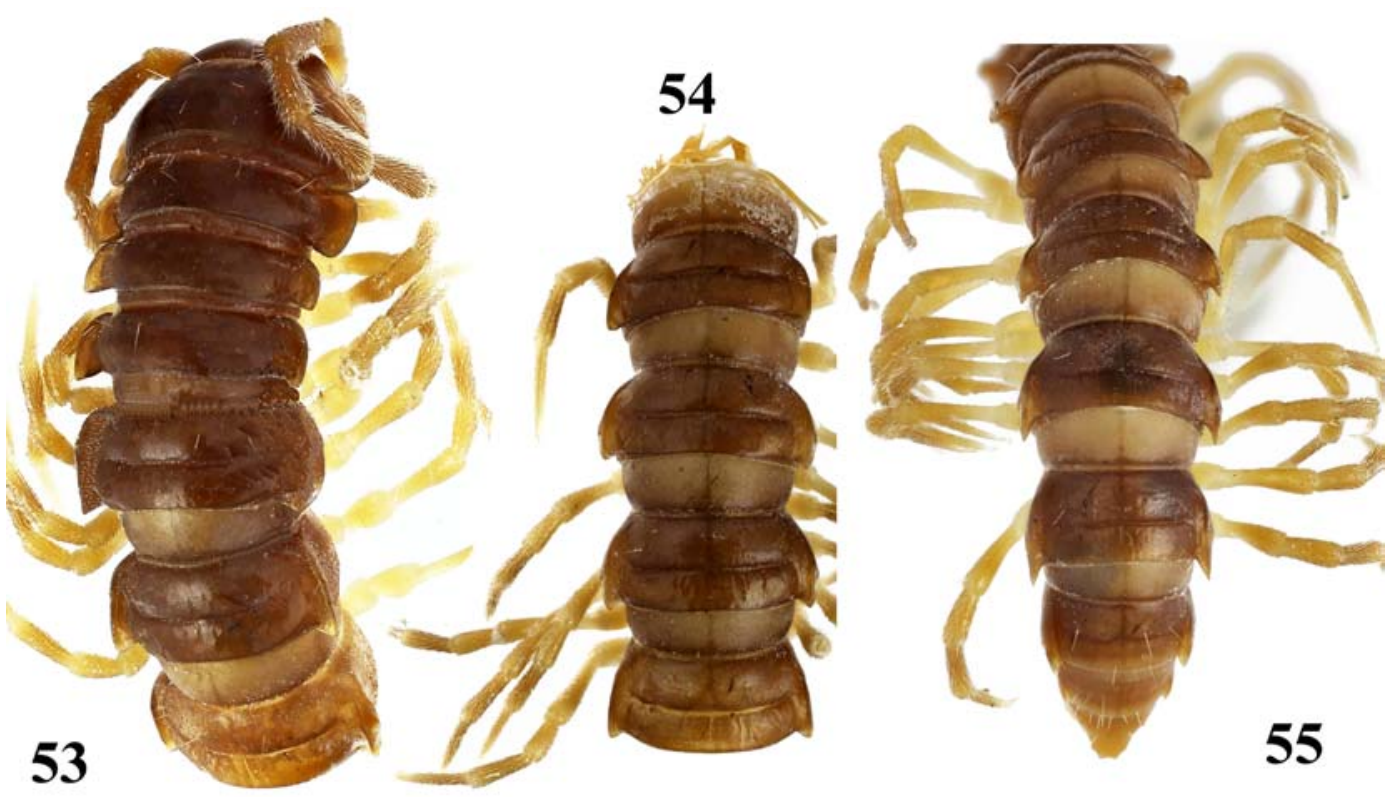

Figs 53-55. Delarthrum curtum sp.n., holotype, anterior, middle and caudal parts of body, respectively, dorsal views. Photos taken by K. Makarov, not to scale.

Pис. 53-55. Delarthrum curtum sp.n., голотип, соответственно передняя, средняя и задняя части тела, сверху. Фото сделаны К. Макаровым, без масштаба.

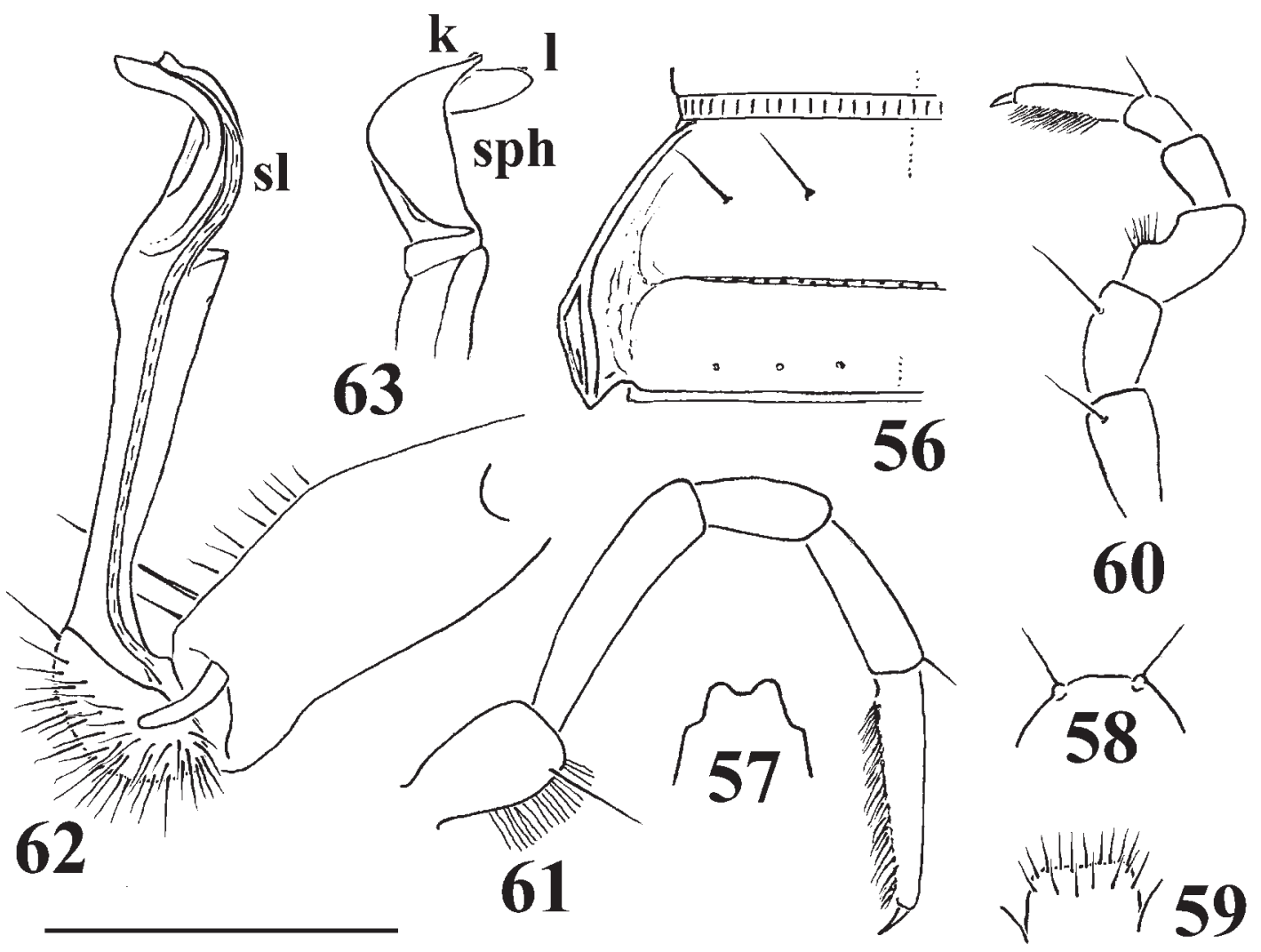

Figs 56-63. Delarthrum curtum sp.n., holotype: 56 - left half of segment 10, dorsal view; 57 - epiproct tip, dorsal view; 58 hypoproct, ventral view; 59 - sternal lobe between coxae 4, caudoventral view; $60-\operatorname{leg} 1$, lateral view; $61-\operatorname{leg} 7$, lateral view; $62-$ right gonopod, mesal view; 63 - distal half of right gonopod, lateral view. Scale bar: 1.0 (56-61) and $0.5 \mathrm{~mm}(62 \& 63)$.

Рис. 56-63. Delarthrum curtum sp.n., голотип: 56 - левая половина сегмента 10, сверху; 57 - кончик эпипрокта, сверху; 58 гипопрокт, снизу; 59 - стернальная пластинка между тазиками 4, одновременно сзади и снизу; 60 - нога 1, сбоку; 61 - нога 7 , сбоку; 62 - правый гонопод, изнутри; 63 - дистальная половина правого гонопода, сбоку. Масштаб 1,0 (56-61) и 0,5 мм (62 и $63)$. 

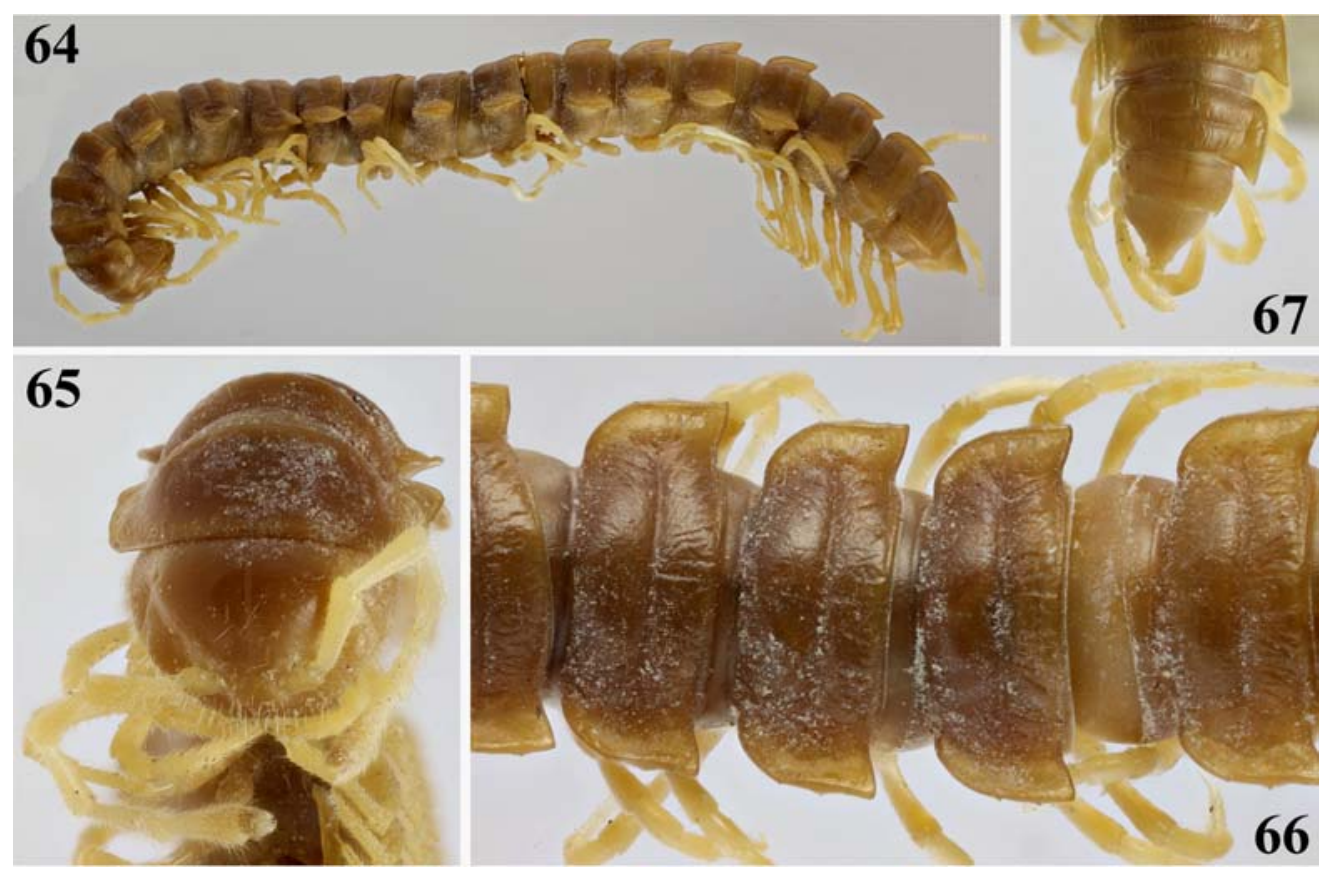

Figs 64-67. Delarthrum tenuitergale sp.n., holotype: 64 - habitus, lateral view; 65- anterior part of body, ventral view; 66 \& 67 middle and caudal parts of body, respectively, dorsal views. Photos taken by K. Makarov, not to scale.

Рис. 64-67. Delarthrum tenuitergale sp.n., голотип: 64 - общий вид, сбоку; 65 - передняя часть тела снизу; 66, 67 соответственно средняя и задняя части тела, сверху. Фото сделаны К. Макаровым, без масштаба.

but differs in the usual, not modified, $\sigma^{7}$ paraterga 5, the caudal corners of all paraterga being drawn, often beak-like, behind the rear tergal margin, and the solenophore very short, stout and simple.

DESCRIPTION. Length of adults ca $20\left(\sigma^{7}\right)$ or 24 $\mathrm{mm}(+)$, width of midbody pro- and metazonae 1.7 and $2.0\left(\sigma^{7}\right)$ or 2.0 and $2.5 \mathrm{~mm}(+)$, respectively. Coloration in alcohol uniformly greyish brown to dark brown with light yellow venter and legs, but the latter infuscate, growing light brown distally (Figs 53-55).

In width, head $=$ segment $3=4<2=5-16<$ collum; starting from segment 17 , body very gently tapering towards telson. Clypeolabral region, frons and front half of vertigial region rather densely setose, remaining vertigial region bare. Antennae rather long and only slightly clavate (Fig. 53), reaching behind until about midway of segment $4\left(\sigma^{7}\right)$ or behind segment $2(+)$ when stretched dorsally; in length, antennomere $2=3=6>4=5>1=7$. Paraterga modest (Figs 53-56), especially so in 9 ; a small, ventrolateral, rimmed, rounded lobule produced behind rear tergal margin in collum and following segments 2 and 3, thereafter caudal corner increasingly spiniform and likewise drawn behind rear tergal margin, in most segments pointed and beak-shaped; paraterga 2 drawn forward about as strongly as caudad; paraterga largely set at about upper $1 / 3$ of midbody height, in lateral view narrow (poreless segments) or thicker (pore-bearing segments) keels; in dorsal view, calluses narrow rims regularly rounded in poreless segments, but broadened and extended into a midway triangle in front of ozopore in pore-bearing segments, delimited by a deep sulcus both dorsally and, only in caudal $1 / 4$ (poreless) or 3/4 (pore-bearing segments), ventrally; $\sigma^{7}$ paraterga 5 unmodified, like any following pore-bearing ones; paraterga 19 particularly small, but evident (Fig. 55). Ozopores lateral, invisible from above, lying inside an ovoid groove at about $1 / 4-1 / 5$ of metatergal length in front of caudal end. Body tegument generally smooth and shining, metaterga mostly faintly, but clearly rugulose, surface below paraterga microgranulate. Axial line very thin and faint, starting from collum. Transverse sulcus deep, finely beaded at bottom and clearly visible on metaterga 5-18, reaching bases of paraterga, incomplete and poorly developed only on $19^{\text {th }}$. Tergal setae long, about $1 / 4-1 / 3$ as long as metaterga, largely abraded, setation pattern often vague, sometimes traceable through insertion points and/or small wrinkles; discarding one marginal seta on each side of collum, the latter at least with $4+4,2+2$ and $3+3$ setae arranged in three transverse rows. Discarding 1-2 setae in front half of paraterga, setation pattern of following metaterga $2-3+2-3$ and 3-4+3-4 setae in two transverse rows, one each in front of and behind sulcus. Stricture dividing pro- and metazonae rather deep and narrow, finely striolate down to level of paraterga (Figs 53-56). Pleurosternal carinae wanting. Epiproct (Figs 55 \& 57) short, tip emarginate, subapical lateral papillae small, but evident. Hypoproct (Fig. 58) roundly subtrapeziform, caudal $1+1$ setae clearly separated, borne on minute knobs.

Sternites without modifications, densely setose, cross-impressions evident; a rather high, linguiform, 
subquadrate, setose lobe between $\sigma^{7}$ coxae 4 (Fig. 59). Legs long, ca 1.7-1.8 $\left(\sigma^{7}\right)$ or 1.4-1.5 times ( $(+)$ as long as midbody height; in $\sigma^{7}$ obviously more crassate (Figs 53-55 \& 57), prefemora rather slender, not swollen laterally, but densely, brush-like setose ventrally; $\sigma^{7}$ femur 1 (Fig. 60) with an evident adenostyle; tarsal brushes gradually thinning out until $\sigma^{\gamma}$ legs 9 (Fig. 61).

Gonopods (Figs 62 \& 63) rather simple; coxite long and slender, subcylindrical, densely setose distolaterally; prefemoral part as usual, densely setose, short, ca $1 / 3$ the length of femorite; the latter simple, slender, suberect, only slightly enlarged distad, without distodorsal tooth, set off from a short acropodite (= solenomere and solenophore) by a clear-cut, oblique, lateral sulcus. Solenophore (sph) very simple, about half as long as femorite, lamellar, twisted, with a rounded apical lobe (I) of a kind of lamina medialis and with a subapical prong (k) marking a still shorter and smaller lamina lateralis, both laminae nearly as long as a rather thick and short solenomere (sl), supporting the latter on mesal side alone.

\section{Delarthrum tenuitergale sp.n.} Figs 64-74.

HOLOTYPE $\sigma^{\top}$ (NMNHS), Nepal, Chandanbari, Langtang National Park, 3250 m a.s.1., 18.07.1981, leg. P. Beron.

PARATYPE: 1 क (NMNHS), same data, together with holotype.

NAME. To emphasize the subequally thin poreless and pore-bearing paraterga.

DIAGNOSIS. Being a typical ex-Parorthomorpha, this new species keys out as D. intermedium (Golovatch, 1994) or D. spectabile (Golovatch, 1994) (see Golovatch [1994] and also above), but differs in the poreless and pore-bearing paraterga/calluses being nearly equally thin both in lateral and dorsal views, as well as by a different shape of the solenophore and a clearly longer solenomere.

DESCRIPTION. Length ca $26\left(\sigma^{7}\right)$ or $28 \mathrm{~mm}(+)$, width of midbody pro- and metazonae 2.0 and $3.0\left(\mathrm{O}^{7}\right)$ or 2.8 and $3.5 \mathrm{~mm}(+)$, respectively. Coloration in alcohol uniformly light grey-yellow to marbled greybrown with lighter, ochraceous paraterga; antennae, venter and legs yellow, a little lighter in $\sigma^{7}$ (Figs 64 67).

In width, head $=$ segment $3=4<$ collum $<2<5$ 16 ; thereafter body very gently tapering. Clypeolabral region and frons densely setose, vertigial region more sparsely so. Antennae rather long and only slightly clavate (Figs $64 \& 65$ ), reaching behind $\left(O^{7}\right)$ or until about midway $(+)$ of segment 3 when stretched dorsally; in length, antennomere $2=3=4=5>6>1=7$. Paraterga well-developed (Figs 64-66), especially so in $\sigma^{7}$, largely subhorizontal, set high, lying at about upper 1/3-1/4 of midbody height; collum rimmed, broadly and regularly rounded laterally, nearly not elevated caudolaterally, with a marginal seta in front $1 / 3$, dorsal surface probably with $4+4,2+2$ and $? 3+3$ setae in three transverse rows, setae mostly being abraded and barely traceable through insertion points; paraterga 2 with broadly rounded lobules slightly produced both forward and behind rear tergal margin; both in lateral and dorsal views, following paraterga and calluses thin, only barely thicker in pore-bearing segments than in poreless ones, caudal corners increasingly acutangular, mostly narrowly rounded until segment 16 , pointed and beak-shaped thereafter, clearly produced caudad behind tergal margin, starting from segment 11 or $12\left(\sigma^{7},+\right)$. Postcollum paraterga with a minute incision in front $1 / 3$ obviously marking the insertion point of a marginal seta. Calluses narrow rims regularly rounded in poreless segments, but usually very faintly broadened and extended into a midway triangle in front of ozopore, delimited by a deep sulcus both dorsally and, only in caudal $1 / 4$ in pore-bearing segments, ventrally; $\sigma^{7}$ paraterga 5 unmodified, like any following porebearing ones; paraterga 19 particularly small, but evident (Fig. 67). Ozopores lateral, invisible from above, lying inside an ovoid groove at about $1 / 4$ of metatergal length in front of caudal margin. Body tegument generally smooth and shining, metaterga mostly faintly, but clearly rugulose, surface below paraterga microgranulate. Axial line very thin and faint, starting from collum and barely traceable on following metaterga. Transverse sulcus deep, finely beaded at bottom and clearly visible on metaterga 5-18, reaching bases of paraterga, incomplete and poorly developed only on $19^{\text {th }}$. Setae on postcollum metaterga retained only in fore row on segment 2, about $1 / 4$ as long as metatergum, but setation pattern often traceable through insertion points and/or wrinkles probably as $2+2$ and $4+4$ in two transverse rows, one each in front of and behind sulcus. Stricture dividing pro- and metazonae rather deep and narrow, finely striolate down to level of paraterga (Fig. 66). Pleurosternal carinae only small ridges in segment 2, thereafter wanting. Epiproct (Figs 67 \& 68) short, tip slightly concave, subapical lateral papillae small, but evident. Hypoproct (Fig. 69) subtrapeziform, caudal edge emarginate, $1+1$ setae modestly separated, not borne on knobs.

Sternites without modifications, densely setose, cross-impressions evident; a rather high, linguiform, subquadrate, setose lobe between $\sigma^{7}$ coxae 4 (Fig. 70). Legs long, ca 1.7-1.8 $\left(\sigma^{7}\right)$ or 1.4-1.5 times $(+)$ as long as midbody height; in $\sigma^{7}$ obviously crassate (Figs 6467 \& 71), prefemora rather slender, not swollen laterally; $\sigma^{\gamma}$ femur 1 with a small adenostyle; tarsal brushes gradually thinning out until $O^{7}$ legs 7 (Fig. 71).

Gonopods (Figs 72-74) rather simple; coxite long and slender, subcylindrical, densely setose distolaterally; prefemoral part as usual, densely setose, short, ca $1 / 3$ as long as femorite; the latter simple, slender, suberect, not enlarged distad, without distodorsal tooth, set off from a short acropodite (= solenomere and solenophore) by a clear-cut oblique cingulum. Solenophore (sph) very simple, ca 1/3 as long as femorite, lamellar, twisted, with a rounded apical lobe (l) of a kind of lamina medialis and a much smaller, shorter and simi- 

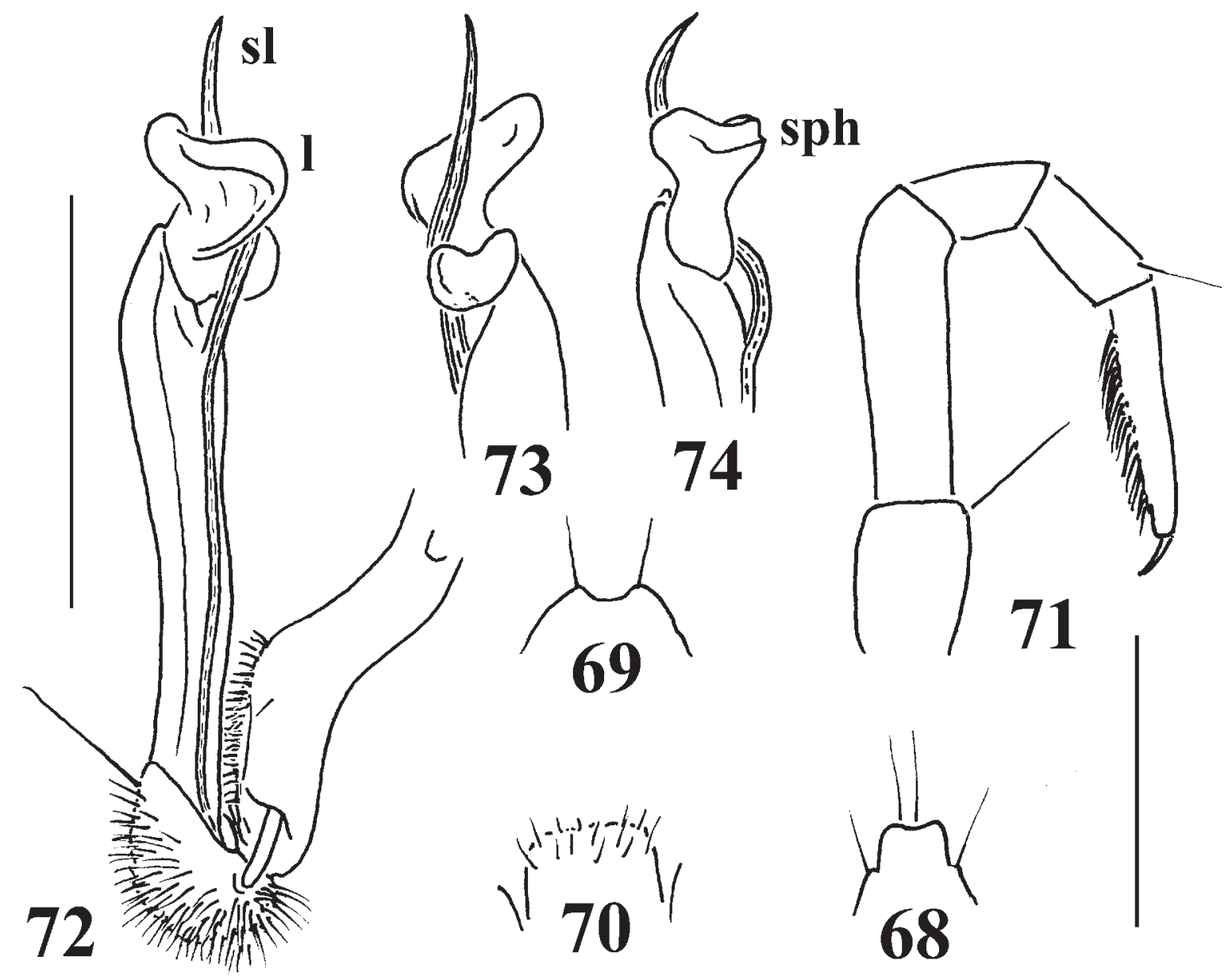

Figs 68-74. Delarthrum tenuitergale sp.n., holotype: 68 - epiproct tip, dorsal view; 69 - hypoproct, ventral view; 70 - sternal lobe between coxae 4, caudoventral view; 71 - leg 4, lateral view; 72 - right gonopod, mesal view; 73 \& 74 - distal half of right gonopod, lateral and ventral views, respectively. Scale bars: $1.0(68-71)$ and $1.0 \mathrm{~mm}(72-74)$.

Рис. 68-74. Delarthrum tenuitergale sp.n., голотип: 68 - кончик эпипрокта, сверху; 69 - гипопрокт, снизу; 70 - стернальная пластинка между тазиками 4, одновременно сзади и снизу; 71 - нога 4, сбоку; 72 - правый гонопод, изнутри; $73,74-$ дистальная половина правого гонопода, соответственно сбоку и снизу. Масштаб 1,0 (68-71) и 1,0 мм (72-74).

larly rounded lamina lateralis, both laminae being about half as long as a rather thin, ribbon-shaped, suberect and relatively long solenomere (sl) they support between themselves.

\section{Delarthrum andreevi sp.n.}

Figs 75-85.

HOLOTYPE $\sigma^{7}$ (NMNHS), Nepal, Pokhara - Annapurna trek, above Bhichuk, $1800 \mathrm{~m}$ a.s.1., 8.10.1984, leg. P. Beron \& S. Andreev.

PARATYPE: 1 (NMNHS), same data, together with holotype.

NAME. Honours Stoitse Andreev, my good friend and one of the collectors.

DIAGNOSIS. Being a typical ex-Parorthomorpha, this new species keys out as $D$. intermedium (Golovatch, 1994) or D. spectabile (Golovatch, 1994) (see Golovatch [1994] and also above), but differs from both by the presence of sternal cones $\left(\mathrm{O}^{7}\right)$ and a slightly different shape of the solenophore, from the former species also by a deeply bipartite solenophore, from the latter one by enlarged, modified $\sigma^{x}$ paraterga 5 .

DESCRIPTION. Length ca $22-23 \mathrm{~mm}$, width of midbody pro- and metazonae 1.9 and 2.6 (holotype) or 2.2 and $2.7 \mathrm{~mm}$ (paratype), respectively. Coloration in alcohol uniformly chocolate brown with only a little lighter, somewhat ochraceous paraterga; antennae light brown, infuscate distally, but tip whitish; tip of epiproct, venter and legs light yellow-brown (Figs 75-78)

In width, head $=$ segment $3=4<$ collum $=2=6-16$ $<5$; starting from segment 17 , body very gently tapering. Clypeolabral region and frons densely setose, vertigial region with a few setae only. Antennae rather long and only slightly clavate (Figs $75 \& 76$ ), reaching behind segment $3\left(\mathrm{O}^{7}\right)$ or $2(+)$ when stretched dorsally; in length, antennomere $2>3=4>5=6>1=7$. Paraterga rather well-developed (Figs 75-78), especially well so in $\sigma^{7}$, largely subhorizontal, set high, 

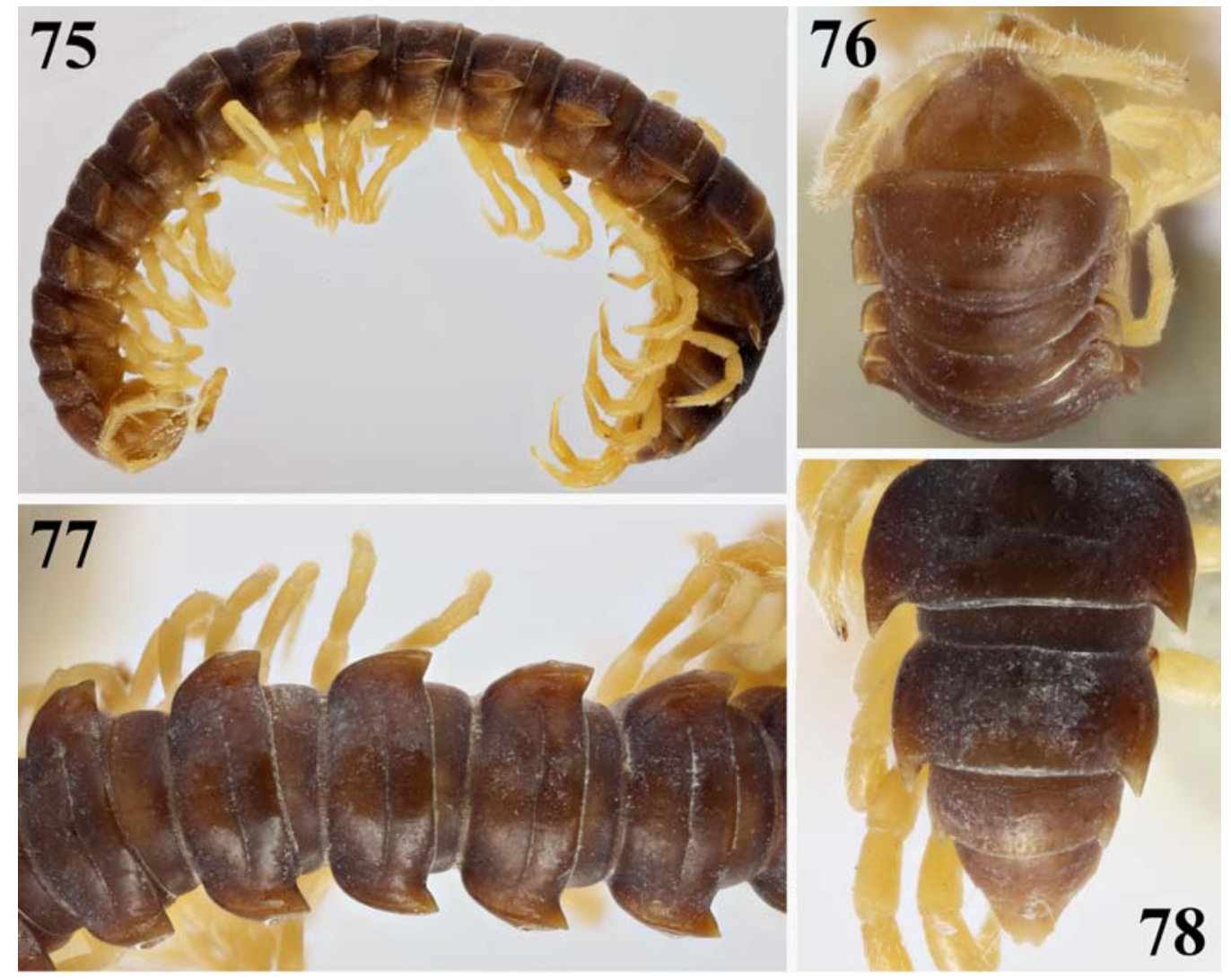

Figs 75-78. Delarthrum andreevi sp.n., holotype: 75 - habitus, lateral view; 76-78 - anterior, middle and caudal parts of body, respectively, dorsal views. Photos taken by K. Makarov, not to scale.

Рис. 75-78. Delarthrum andreevi sp.n., голотип: 75 - общий вид, сбоку; 76-78 - соответственно передняя, средняя и задняя части тела, сверху. Фото сделаны К. Макаровым, без масштаба.

lying at about upper 1/3-1/4 of midbody height; collum rimmed, with two long marginal setae in front of an obtusangular, broadly rounded, slightly elevated, caudolateral flap very faintly drawn back behind rear tergal margin; paraterga 2 narrow and low-lying ridges drawn a little forward and, much more clearly, back at ca $80^{\circ}$ behind tergal margin, nearly pointed, with two similarly long marginal setae in front half; caudal corners of following paraterga largely spiniform, at least slightly and increasingly well produced caudally behind margin, starting from segment 11 pointed and beak-shaped; paraterga 5 peculiar (Fig. 75), broader than usual, thick/high and flat ridges demarcated by equally well-developed and complete dorsal and ventral sulci, hollow beneath, but unsually strongly swollen below in pleurosternal region; calluses thin, regularly rounded and especially thin on poreless paraterga, a little thicker and usually sinuate in front of ozopore on all pore-bearing paraterga behind $5^{\text {th }}$ whence ventral demarcating sulcus present only to about posterior $2 / 3$ of paratergal length, but virtually absent from poreless ones. Paraterga 19 particularly small, but evident (Fig. 78). Ozopores lateral, invisible from above, lying inside an ovoid groove at about $1 / 3$ of metatergal length in front of caudal margin. Body tegument smooth and shining, metaterga very faintly rugulose at most, their posterior halves especially clearly so; surface below paraterga microgranulate. Axial line very thin and faint, usually barely traceable on rear halves of postcollum metaterga. Transverse sulcus deep, but thin, finely beaded at bottom and clearly visible on metaterga $5-18$, reaching bases of paraterga, incomplete and very poorly developed only on $4^{\text {th }}$ and $19^{\text {th }}$. Setae on collum mostly retained, pattern probably $4+4,2+2$ and $? 3+3$ in three transverse rows (Fig. 76), following setae ca $1 / 5$ $1 / 4$ as long as metaterga, nearly fully abraded, setation pattern too vague to be traceable even through insertion points, but at least $2+2$ setae visible in front row. Stricture dividing pro- and metazonae rather deep and narrow, finely striolate down to level of paraterga (Fig. 77). Pleurosternal carinae small ridges present only in segment 2 , thereafter bulges increasingly poorly developed from segment 5 until about $18^{\text {th }}$. Epiproct (Figs 78 \& 79) short, tip emarginate, subapical lateral papillae small, but evident. Hypoproct (Fig. 80) subtrapeziform, caudal $1+1$ setae strongly separated, not borne on knobs.

Sternites densely setose, cross-impressions evident; starting from segment 9, each coxa with a small, caudal, sternal cone nearby; a rather high, trapeziform, 


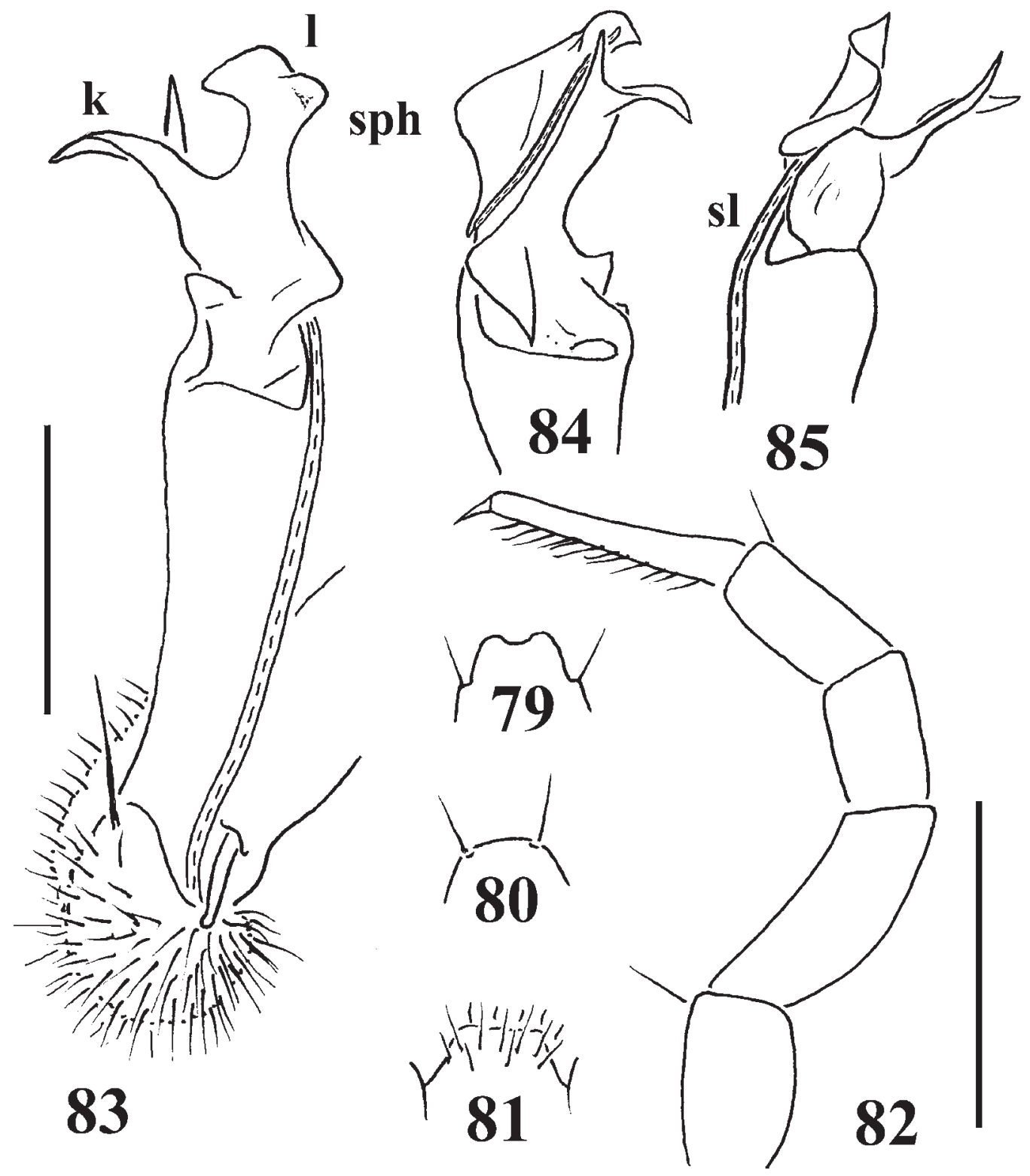

Figs 79-85. Delarthrum andreevi sp.n., holotype: 79 - epiproct tip, dorsal view; 80 - hypoproct, ventral view; 81 - sternal lobe between coxae 4, caudoventral view; 82 - midbody leg, lateral view; 83 - right gonopod, mesal view; $84 \& 85$ - distal half of right gonopod, sublateral and dorsal views, respectively. Scale bars: 1.0 (79-82) and $1.0 \mathrm{~mm}(83-85)$.

Рис. 79-85. Delarthrum andreevi sp.n., голотип: 79 - кончик эпипрокта, сверху; 80 - гипопрокт, снизу; 81 - стернальная пластинка между тазиками 4, одновременно сзади и снизу; 82 - среднетуловищная нога, сбоку; 83 - правый гонопод, изнутри; 84, 85 - дистальная половина правого гонопода, соответственно почти сбоку и сверху. Масштаб 1,0 (79-82) и 1,0 мм (83-85).

setose lobe between $\sigma^{7}$ coxae 4 (Fig. 81). Legs long, ca $1.6-1.7\left(\bigcirc^{7}\right)$ or 1.2-1.3 ( $(+)$ times as long as midbody height, in $O^{7}$ obviously crassate (Figs $75 \& 82$ ), prefemora rather slender, not swollen laterally; $\sigma^{7}$ femur 1 with a small adenostyle; distotibial and tarsal brushes gradually thinning out until $\sigma^{7}$ legs of segment 9 .

Gonopods (Figs 83-85) rather simple; coxite long and slender, subcylindrical, densely setose distolaterally; prefemoral part as usual, densely setose, short, ca $1 / 2$ the length of femorite; the latter simple, slender, suberect, only very faintly enlarged distad, without distodorsal tooth, set off from a short acropodite (= solenomere and solenophore) by a clear-cut oblique cingulum. Solenophore (sph) simple, ca 1/2 as long as femorite, lamellar, twisted, from about midway bipartite, with a rounded apical lobe (I) of a kind of lamina medialis and a much slenderer, bifurcate and acuminate lamina lateralis (k), both laminae being about as long as a thin, ribbon-shaped, suberect and short solenomere (sl) they support between themselves. 

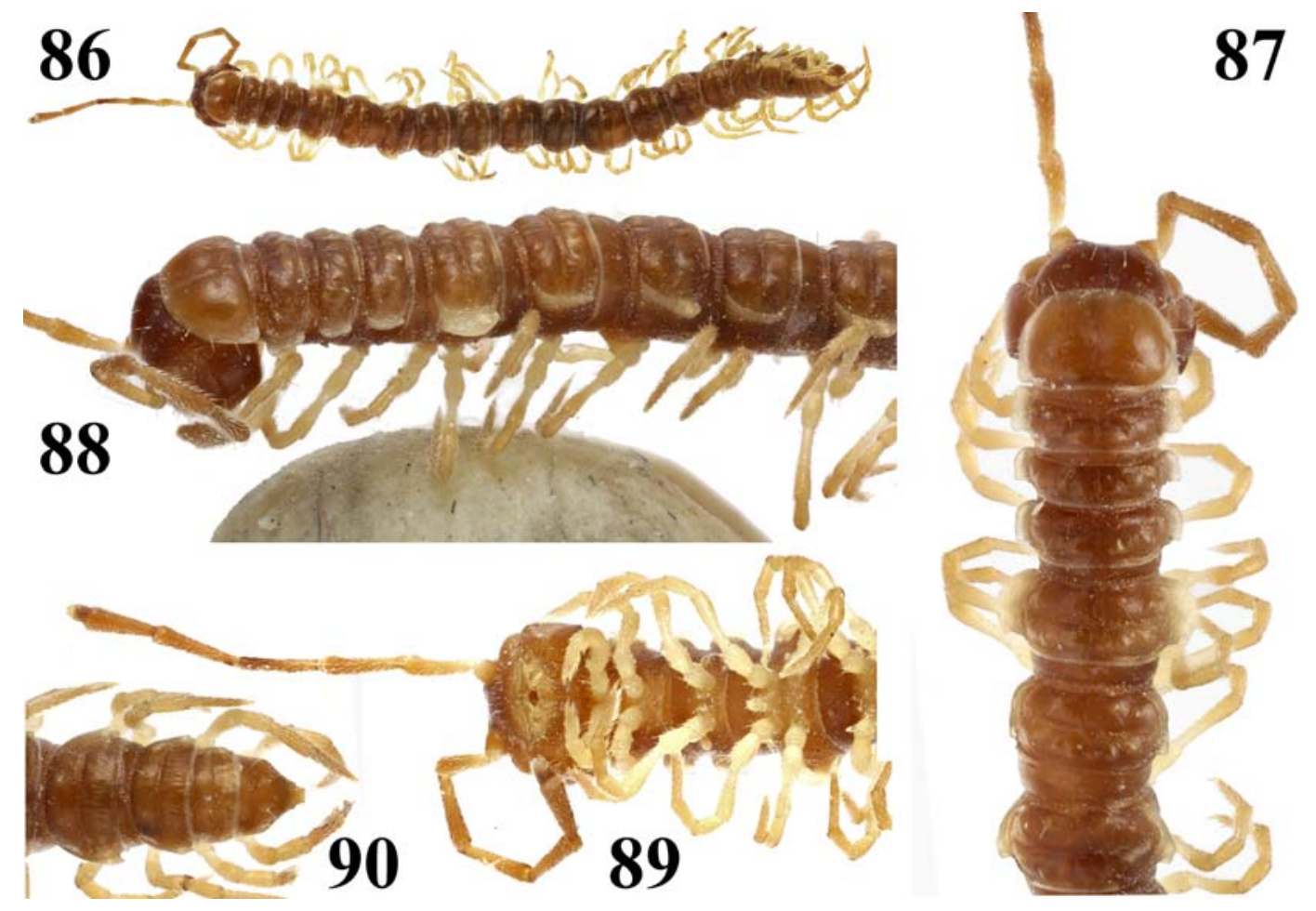

Figs 86-90. Delarthrum heterotergale sp.n., holotype: 86 - habitus, dorsal view; 87-89 - anterior part of body, dorsal, dorsolateral and ventral views, respectively; 90 - caudal part of body, dorsal view. Photos taken by K. Makarov, not to scale.

Рис. 86-90. Delarthrum heterotergale sp.n., голотип: 86 - общий вид, сверху; 87-89 - передняя часть тела, соответственно сверху, одновременно сверху и сбоку, а также снизу; 90 - задняя части тела, сверху. Фото сделаны К. Макаровым, без масштаба.

\section{Delarthrum heterotergale sp.n.}

Figs 86-100.

HOLOTYPE $\sigma^{7}$ (NMNHS), Nepal, Betrawati, 600-1000 m a.s.1., 21.07.1981, leg. P. Beron.

PARATYPE: 1 \% (NMNHS), same data, together with holotype.

NAME. To emphasize the conspicuously enlarged $\sigma^{7}$ paraterga 5.

DIAGNOSIS. Being a typical ex-Parorthomorpha, this new species keys out as D. longisetum (Golovatch, 1994) or D. granulosum (Golovatch, 1994) (see Golovatch [1994] and also above), but differs readily from both by a different shape of the solenophore.

DESCRIPTION. Length ca $14\left(\sigma^{7}\right)$ or $16 \mathrm{~mm}(+)$, width of midbody pro- and metazonae 1.0 and $1.2\left(\sigma^{7}\right)$ or 1.5 and $1.7 \mathrm{~mm}(+)$, respectively. Coloration in alcohol rather uniformly grey-brown to brown, with lighter, greyish yellow-brown legs and paraterga/calluses; antennae light brown, slightly infuscate distally, but tip whitish (Figs 86-90).

Body moniliform. In width, collum $=$ segment $3<2$ $=4<$ head $=6-16<5$ (Fig. 87); starting from segment 17 , body very gently tapering. Clypeolabral region and frons densely setose, vertigial region with a few setae only. Antennae very long and subfiliform (Figs 86$89)$, reaching behind segment $4\left(O^{7}\right)$ or $3(+)$ when stretched dorsally; in length, antennomere $2=3>4>5$ $=6>1=7$. Paraterga generally rather modest (Figs
86-90), especially clearly reduced in + , largely slightly declined, set high, lying at about upper $1 / 3-1 / 4$ of midbody height, only $5^{\text {th }}$ in $\sigma^{\text {T }}$ unusually strongly enlarged (Figs 86-88); collum rimmed, with a long marginal seta in front of a small, rounded, slightly elevated, caudolateral flap; paraterga 2 narrow, low-lying and subquadrate ridges drawn neither forward nor caudally (Fig. 87), narrowly rounded on both ends, with at least one similar marginal seta in front $1 / 3$; caudal corners of following paraterga largely acutangular and narrowly rounded, growing increasingly spiniform towards segment 17 (Fig. 90), never produced caudally behind rear tergal margin; paraterga 5 peculiar (Figs $87,88 \& 92$ ), broader than usual, thick/high and rounded ridges demarcated by equally well-developed and complete dorsal and ventral sulci, hollow beneath; calluses especially thin and regularly rounded in poreless paraterga, clearly thicker and usually sinuate in front of ozopore in all pore-bearing paraterga behind $5^{\text {th }}$ (Figs $87 \& 91$ ) whence ventral sulcus present only to about posterior half of paratergal length, but virtually absent from poreless paraterga. Paraterga 19 particularly small, nearly absent (Fig. 90). Ozopores lateral, invisible from above, lying inside an ovoid groove at about $1 / 3$ of metatergal length in front of caudal margin. Body tegument shining, metaterga rather clearly tuberculate and faintly rugulose, their posterior halves especially strongly so; surface below paraterga sometimes finely micro- 


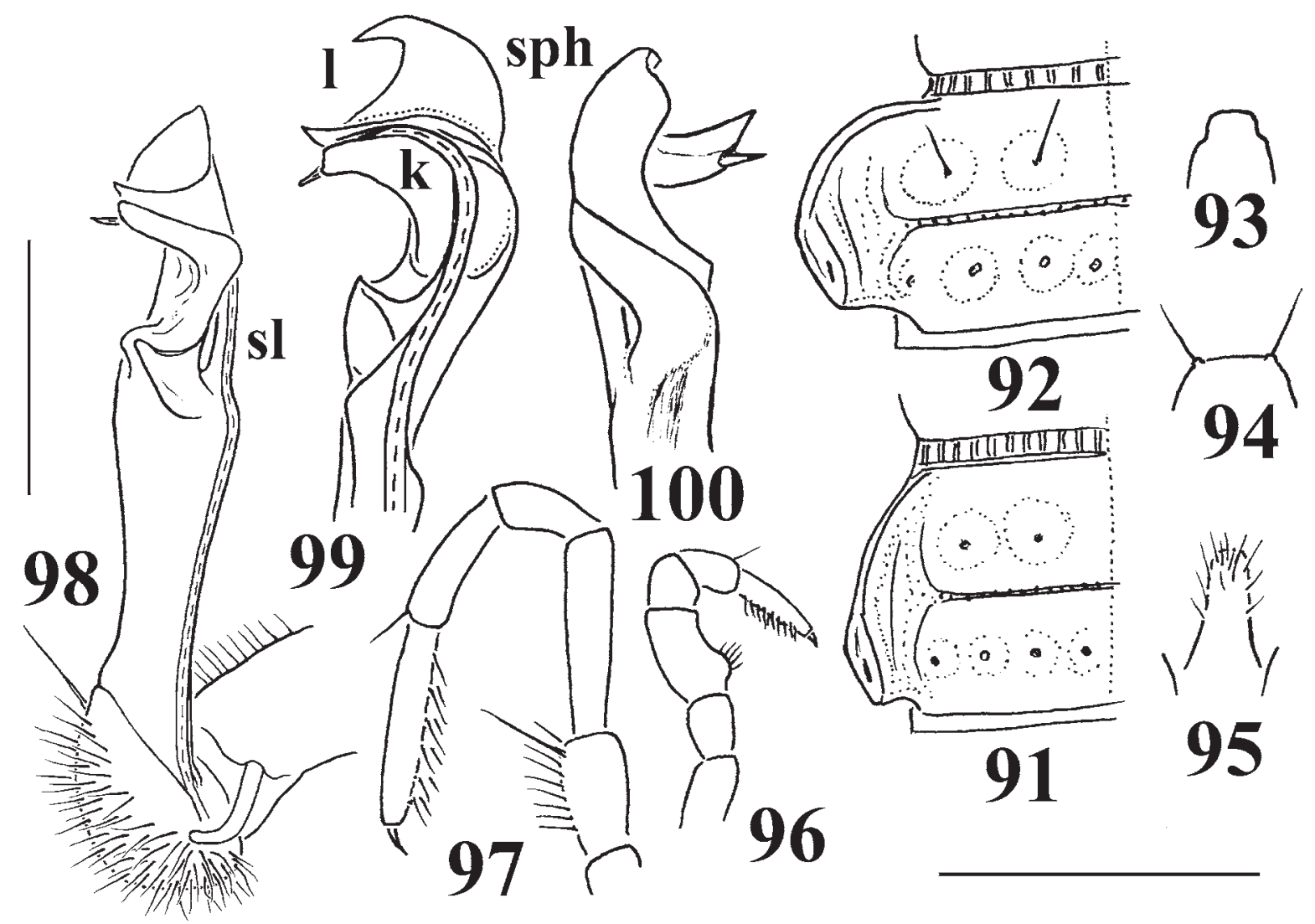

Figs 91-100. Delarthrum heterotergale sp.n., holotype: $91 \& 92$ - left halves of segments 5 and 10, respectively, dorsal views; 93 epiproct tip, dorsal view; 94 - hypoproct, ventral view; 95 - sternal lobe between coxae 4, caudoventral view; 96 \& 97 - legs 1 and 10 , respectively, lateral views; 98 — right gonopod, mesal view; $99 \& 100$ — distal half of right gonopod, ventral and sublateral views, respectively. Scale bars: $1.0(91-97)$ and $0.5 \mathrm{~mm}(98-100)$.

Рис. 91-100. Delarthrum heterotergale sp.n., голотип: 91, 92 - соответственно левые половины сегментов 5 и 10 , сверху; 93 кончик эпипрокта, сверху; 94 - гипопрокт, снизу; 95 - стернальная пластинка между тазиками 4, одновременно сзади и снизу; 96, 97 - соответственно ноги 1 и 10, сбоку; 98 - правый гонопод, изнутри; 99, 100 - дистальная половина правого гонопода, соответственно снизу и почти сбоку. Масштаб 1,0 (91-97) и 0,5 мм (98-100).

granulate. Axial line thin, but evident, starting from collum and visible on all metaterga. Transverse sulcus deep and rather wide, clearly beaded at bottom, incomplete and thinner on metaterga 3, 4 and 19, fully developed on metaterga 5-18 where reaching bases of paraterga. Setae on collum $4+4, ? 1+1$ and ?2+2, arranged in three transverse rows, on postcollum segments rather long, ca 1/3 as long as metaterga, mostly abraded, but setation pattern usually well traceable even through insertion points and tubercles/bosses, obviously being $2+2$ and 3-4+3-4 setae on bosses in two transverse rows, one each in front of and behind sulcus (Figs 91 \& 92). Stricture dividing pro- and metazonae rather deep and broad, very strongly ribbed down to even far below paraterga (Figs 87, 88, 91 \& 92). Pleurosternal carinae wanting. Epiproct (Figs 90 \& 93) short, tip subtruncate, subapical lateral papillae small, but evident. Hypoproct (Fig. 94) subtrapeziform, caudal $1+1$ setae strongly separated, borne on minute knobs.

Sternites without modifications, densely setose, cross-impressions evident; a very high, narrow, rounded, linguiform, setose lobe between $\sigma^{7}$ coxae 4 (Figs
89 \& 95). Legs long, slender, ca 1.6-1.7 ( $\left.\sigma^{7}\right)$ or 1.11.2 times $(+)$ as long as midbody height, in $\sigma^{7}$ somewhat crassate (Figs $75 \& 82$ ), prefemora rather slender, not swollen laterally, but often with peculiar long setae ventrally (Fig. 97); $\bigcirc^{7}$ femur 1 (Fig. 96) with a small, but evident adenostyle; tarsal brushes gradually thinning out towards $\sigma^{7}$ legs 7 .

Gonopods (Figs 98-100) rather simple; coxite long and slender, subcylindrical, densely setose distolaterally; prefemoral part as usual, densely setose, short, ca $1 / 2$ the length of femorite; the latter simple, slender, suberect, only very faintly enlarged distad, without distodorsal tooth, set off from a short acropodite (= solenomere and solenophore) by a clear-cut oblique cingulum. Solenophore (sph) rather simple, only slightly shorter than femorite, lamellar, twisted, from about midway bipartite, with a much higher, longer, acuminate, coiled, apical lobe (I) of a kind of lamina lateralis and with a much smaller, shorter and simpler lamina medialis (k), both laminae being about as long as a thin, ribbon-shaped, suberect and short solenomere (sl) they support between themselves. 


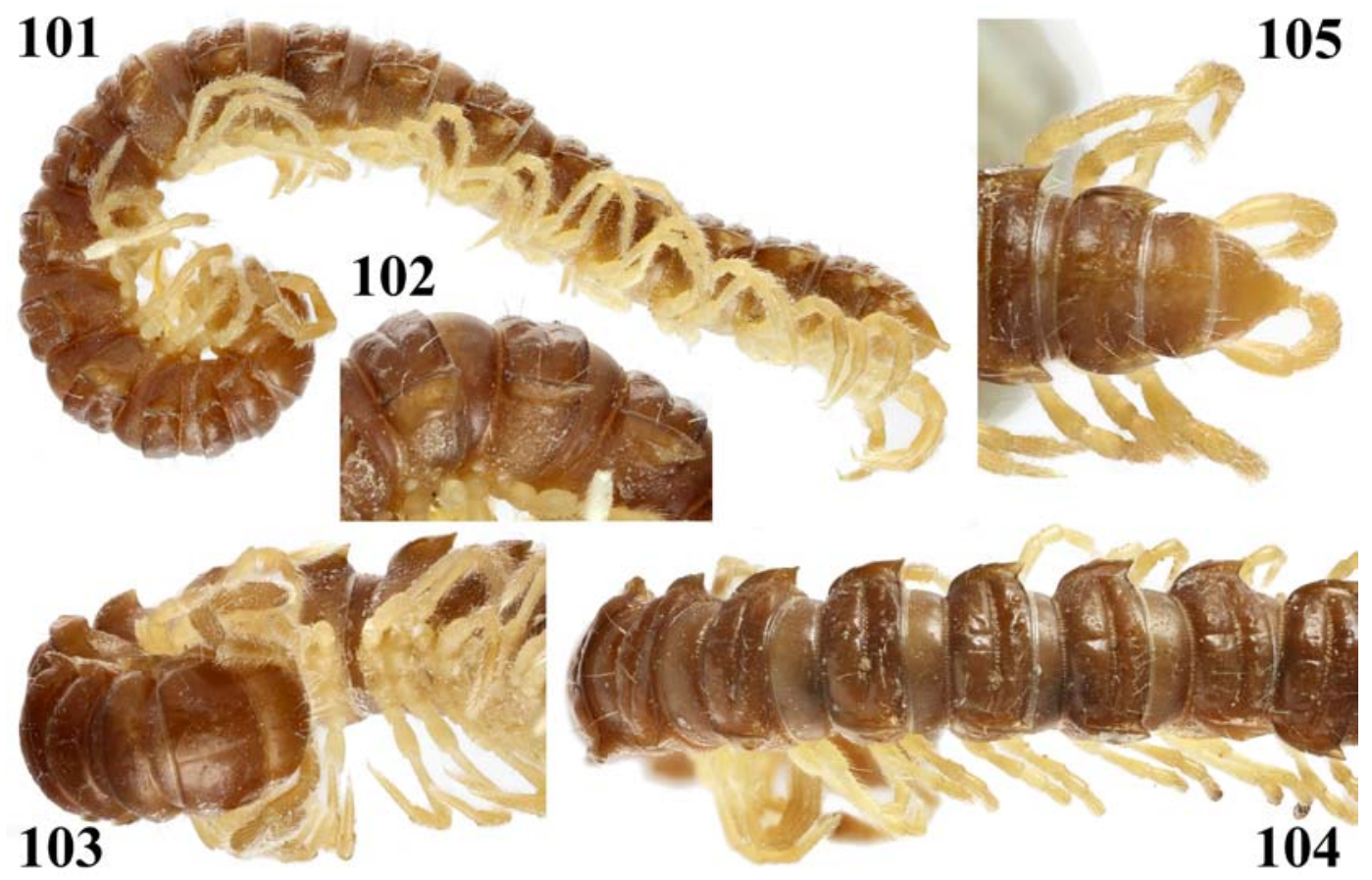

Figs 101-105. Delarthrum setosum sp.n., holotype: 101 - habitus, lateral view; 102 — segments 5-7 enlarged, lateral view; 103 anterior part of body, ventral view; 104 \& 105 - middle and caudal parts of body, respectively, dorsal views. Photos taken by K. Makarov, not to scale.

Рис. 101-105. Delarthrum setosum sp.n., голотип: 101 - общий вид, сбоку; 102 - увеличенные сегменты 5-7, сбоку; 103 — передняя часть тела, снизу; 104, 105 - соответственно средняя и задняя части тела, сверху. Фото сделаны К. Макаровым, без масштаба. $87-89$

\section{Delarthrum setosum sp.n.}

Figs 101-111.

HOLOTYPE Ơ $^{7}$ (NMNHS), Nepal, Tansen, Lumbini Zone, 6.07.1981, leg. P. Beron.

PARATYPE: $1 O^{7}$ (NMNHS), same data, together with holotype.

NAME. To emphasize the conspicuously dense tergal setae.

DIAGNOSIS. Being a typical ex-Parorthomorpha, this new species keys out as $O$. longisetum (Golovatch, 1994) or O. spectabile (Golovatch, 1994) (see Golovatch [1994] and also above), but differs from both in a clearly different shape of the solenophore.

DESCRIPTION. Length of both $\sigma^{7} \sigma^{7}$ ca $15 \mathrm{~mm}$, width of midbody pro- and metazonae 1.0 and $1.5 \mathrm{~mm}$, respectively. Coloration in alcohol uniformly brown; antennae light brown, slightly infuscate distally, but tip whitish; tip of epiproct, venter and legs light greybrown (Figs 101-105).

In width, collum $=$ segment $3<2=4<$ head $=5$ 16 ; thereafter body very gently tapering. Clypeolabral region, frons and front half of vertigial region densely setose, rear half of vertex bare. Antennae mediumsized, only slightly clavate (Figs 102 \& 103), reaching behind segment 2 when stretched dorsally $\left(\sigma^{7}\right)$; in length, antennomere $2=3=6>4=5>1=7$. Paraterga medium-sized (Figs 101-106), largely subhorizontal, set high, lying at about upper 1/3 of midbody height; collum rimmed, with an angular, obtuse (ca $100^{\circ}$ ), rather narrowly rounded, slightly elevated, caudolateral flap very faintly drawn back behind rear tergal margin; paraterga 2 narrow, middle arcuate dorsad, low-lying ridges with thee long marginal setae, drawn into rounded lappets both a little forward and, much more clearly, back at ca $80^{\circ}$ behind tergal margin; following paraterga with two marginal, setigerous incisions at about each $1 / 3$ extent, their caudal corners largely spiniform, pointed and beak-like, starting from segment 15 increasingly clearly produced caudally behind the margin; paraterga 5 peculiar (Fig. 102), much thicker/ higher than usual, flat ridges demarcated by equally well-developed and complete dorsal and ventral sulci, hollow beneath; calluses thin, regularly rounded and especially thin in poreless paraterga, a little thicker and faintly sinuate in front of ozopore on all pore-bearing paraterga behind $5^{\text {th }}$ whence ventral demarcating sulcus present only to about posterior $1 / 4$ or $3 / 4$ of paratergal length in poreless and pore-bearing segments, respectively; paraterga 19 particularly small, but evident (Fig. 105). Ozopores lateral, invisible from above, lying inside an ovoid groove at about $1 / 4$ of metatergal length in front of caudal margin. Body tegument shining, metaterga mostly rugulose to rugose and often also microtuberculate due to setigerous knobs, surface be- 

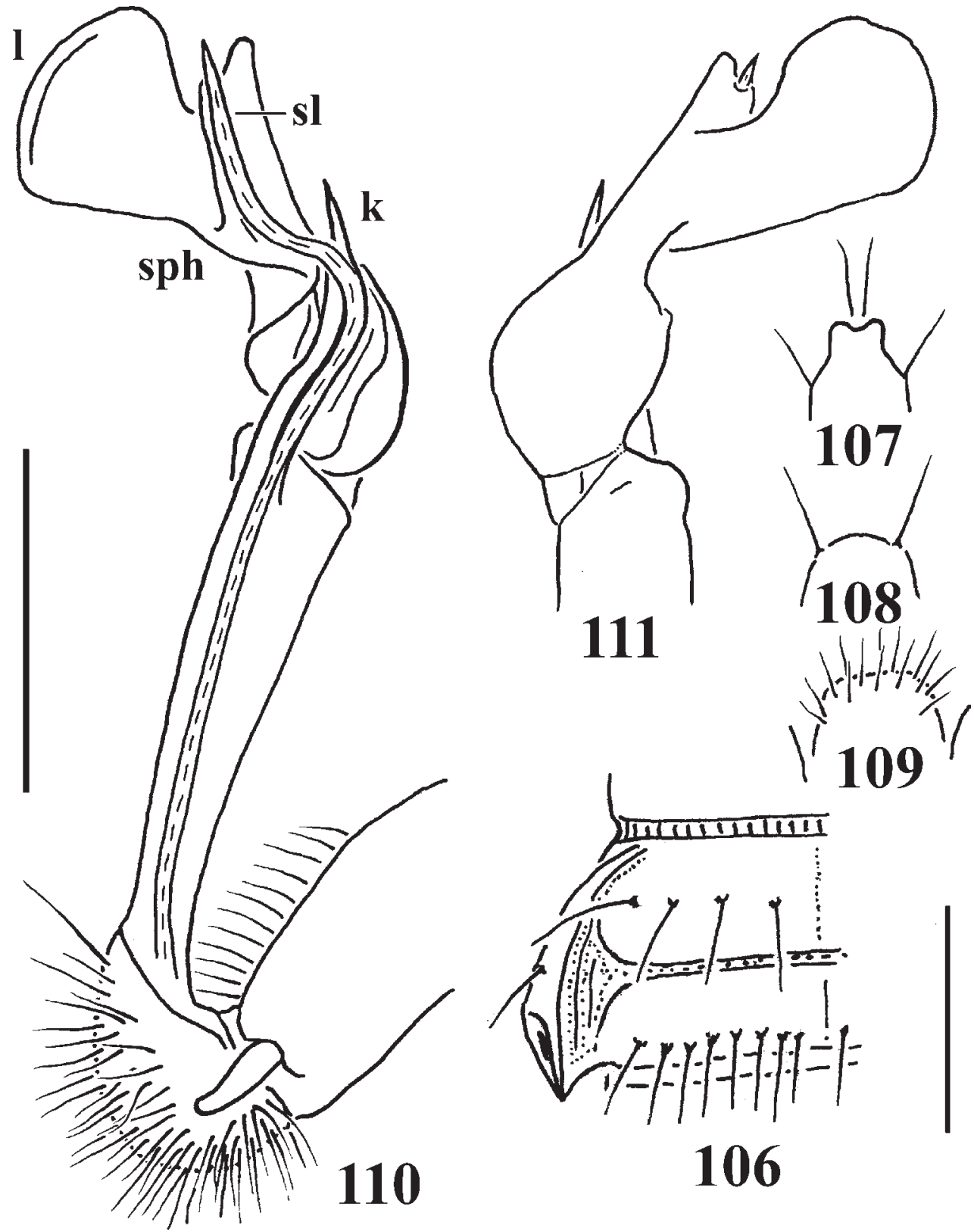

106

Figs 106-111. Delarthrum setosum sp.n., holotype: 106 - left half of segment 10, dorsal view; 107 - epiproct tip, dorsal view; 108 - hypoproct, ventral view; 109 - sternal lobe between coxae 4, caudoventral view; 110 - right gonopod, mesal view; 111 — distal half of right gonopod, lateral view. Scale bars: $0.5(106-109)$ and $0.25 \mathrm{~mm}(110 \& 111)$.

Рис. 106-111. Delarthrum setosum sp.n., голотип: 106 - левая половина сегмента 10, сверху; 107 — кончик эпипрокта, сверху; 108 - гипопрокт, снизу; 109 - стернальная пластинка между тазиками 4, одновременно сзади и снизу; 110 - правый гонопод, изнутри; 111 - дистальная половина правого гонопода, сбоку. Масштаб 0,5 (106-109) и 0,25 мм (110 и 111).

low paraterga microgranulate. Axial line mostly deep and clear, starting already from collum (Figs 103 \& 104). Transverse sulcus deep, rather broad, clearly beaded at bottom, fully developed on metaterga 5-18, reaching bases of paraterga, incomplete and very poorly developed only on $4^{\text {th }}$. Tergal setae long, often up to half as long as metaterga, mostly retained, usually abundant, setation pattern normally clearly traceable through insertion knobs or points when broken off, on collum $4+4,2+2$ and $3+3$ in three transverse rows (Fig. 103), on following metaterga arranged in 2-4 transverse rows: 1-2 lying in front of, the other 1-2 behind transverse sulcus; first row always $4+4$, gradually growing double towards a few caudalmost segments, $4+4$ and $2+2$ or $4+4$ and $3+3$, while first postsulcus row at first $4+4$, then gradually growing $5+5,6+6$ or $7+7$ towards midbody segments (Fig. 106), thereafter postsulcus row also turning double, less regular, up to $6+6$ or $7+7$ in each of rows 3 and 4 on a few caudalmost segments. Stricture dividing pro- and metazonae deep, narrow, 
clearly ribbed down to level of paraterga (Figs $102 \&$ 104). Pleurosternal carinae very small ridges only in segments 2-4, turning into modest, increasingly poorly developed bulges in a few following segments. Epiproct (Figs $105 \& 107$ ) short, tip emarginate, subapical lateral papillae small, but evident. Hypoproct (Fig. 108) nearly semi-circular, caudal $1+1$ setae strongly separated, not borne on knobs.

Sternites without modifications, rather densely setose, cross-impressions evident; a rather high, subtrapeziform, setose lobe between coxae 4 (Fig. 109). Legs long, ca 1.7-1.8 times as long as midbody height $\left(\sigma^{7}\right)$, obviously crassate (Fig. 101), prefemora rather slender, not swollen laterally; femur 1 without adenostyle; tarsal brushes gradually thinning out already until legs 4 .

Gonopods (Figs 110 \& 111) rather simple; coxite long and slender, subcylindrical, densely setose distolaterally; prefemoral part as usual, densely setose, short, ca $1 / 2$ as long as femorite; the latter simple, slender, suberect, only very faintly enlarged distad, without distodorsal tooth, set off from a rather long acropodite (= solenomere and solenophore) by a clear-cut oblique cingulum. Solenophore (sph) simple, mostly lateral, comparable in length to femorite, lamellar, twisted, in about proximal $1 / 3$ with a small, but conspicuous front spine (k) followed by a lobe supporting the end portion of a fully mesal, ribbon-shaped solenomere (sl) and then by a large, rounded, apical lobe (I).

\section{Beronodesmus gen.n.}

DIAGNOSIS. Medium-sized Chamberlinini (about $2 \mathrm{~cm}$ long) with 20 segments, poorly developed paraterga, a lobe between $\sigma^{7}$ coxae 4 , and an adenostyle on $\sigma^{7}$ femur 1.

Gonopod coxa subcylindrical. Prefemoral (= densely setose) portion much shorter than an elongate and suberect femorite, the latter not twisted (= seminal groove running entirely on mesal side), distally without a lateral sulcus to demarcate a postfemoral region, but with two processes, distalmost of which lying at base of a clear-cut geniculation marking the onset of a long flagelliform solenomere supported by a similarly long, mesally directed, simple, ribbon-shaped solenophore.

Type species: Beronodesmus pallidus sp.n.

REMARKS. The Oriental tribe Chamberlinini has recently been revised [Chen et al., 2010; Nguyen Duc \& Korsós, 2011] and shown to comprise six genera primarily characterized by the gonopods which share a distinct geniculation cingulum between the distal end of a typically slender and untwisted femorite or postfemoral part (when the latter is distinguished basally due to an oblique distolateral sulcus on the femorite) and the acropodite. The solenomere, either thick (Chamberlinius Wang, 1956, Simplogonomorpha Nguyen Duc et Korsós, 2011 and Riukiupeltis Verhoeff, 1939) or thin and flagelliform (Haplogonosoma Brölemann, 1916, Aponedyopus Verhoeff, 1939 and Geniculodesmus Chen, Golovatch et Chang, 2008), and a soleno- phore if any, both start distal to the geniculation. A more or less distinct tooth lying just proximal to it is only present in Chamberlinius and Haplogonosoma. Following the geniculation, the acropodite is typically very long, directed mesad, strongly coiled and often subcircular. A solenophore supporting, sheathing or accompanying the solenomere is usually prominent, being rudimentary only in Riukiupeltis or even totally suppressed in Simplogonomorpha. Beronodesmus gen.n. is thus unique in showing no gonopod postfemoral part, combined with two distinct teeth observed before the geniculation while the solenomere is thereby flagelliform and the solenophore prominent and ribbon-shaped.

Another unique feature of Beronodesmus gen.n. is the presence of a distinct adenostyle on each $\sigma^{7}$ femur 1. This character only seldom occurs in species of the subfamily Paradoxosomatinae, being more common in Alogolykinae and, especially, Australiosomatinae [e.g. Golovatch, 2014].

Very strong paraterga are only observed in Chamberlinius and Riukiupeltis, but more often they are poorly developed (Simplogonomorpha) to nearly wanting (Aponedyopus, Geniculodesmus and Haplogonosoma). In this respect, Beronodesmus gen.n. resembles the latter three genera.

Regrettably, the identity of Tonkinosoma jeekeli Nguyen Duc, 2011, a species described rather recently from northern Vietnam [Nguyen Duc, 2011], is obscure. The configuration of the gonopod, especially its midway geniculation, strongly resembles that of a typical Chamberlinini, but the solenomere, as well as the solenophore if any have been described and illustrated far from adequately. It remains unclear if the solenomere is flagelliform and sheathed by the solenophore, as claimed, or actually thick and lacks a solenophore. Since the type species, T. flexipes Jeekel, 1953, also from northern Vietnam [Jeekel, 1953], shows no gonopod geniculation, but has a clear-cut process placed basal to the beginning of a flagelliform solenomere, the generic allocation of $T$. jeekeli is to be questioned. I am inclined to consider Tonkinosoma Jeekel, 1953 as a member of the large, mostly Asian tribe Sulciferini, whereas " $T$." jeekeli is probably a Chamberlinini requiring revision.

Below is the first species of Chamberlinini to be found in the Himalayas.

\section{Beronodesmus pallidus sp.n.}

Figs 112-123.

HOLOTYPE $0^{7}$ (NMNHS), Nepal, Langtang Valley, Kyangjin, Gompa Forest, 3800-4100 m, 23.09.1984, leg. P. Beron.

PARATYPES: $15 \sigma^{7} \sigma^{7}, 10$ 우, 3 juv. (NMNHS), $2 \sigma^{7} \sigma^{7}, 1$ ㅇ (ZMUM 02370 ), same locality, together with holotype.

NAME. The generic epithet honours Petar Beron, an outstanding Bulgarian zoologist who collected most of the material treated here. The species name emphasizes the pale coloration of the animals (NB: alcohol material). 

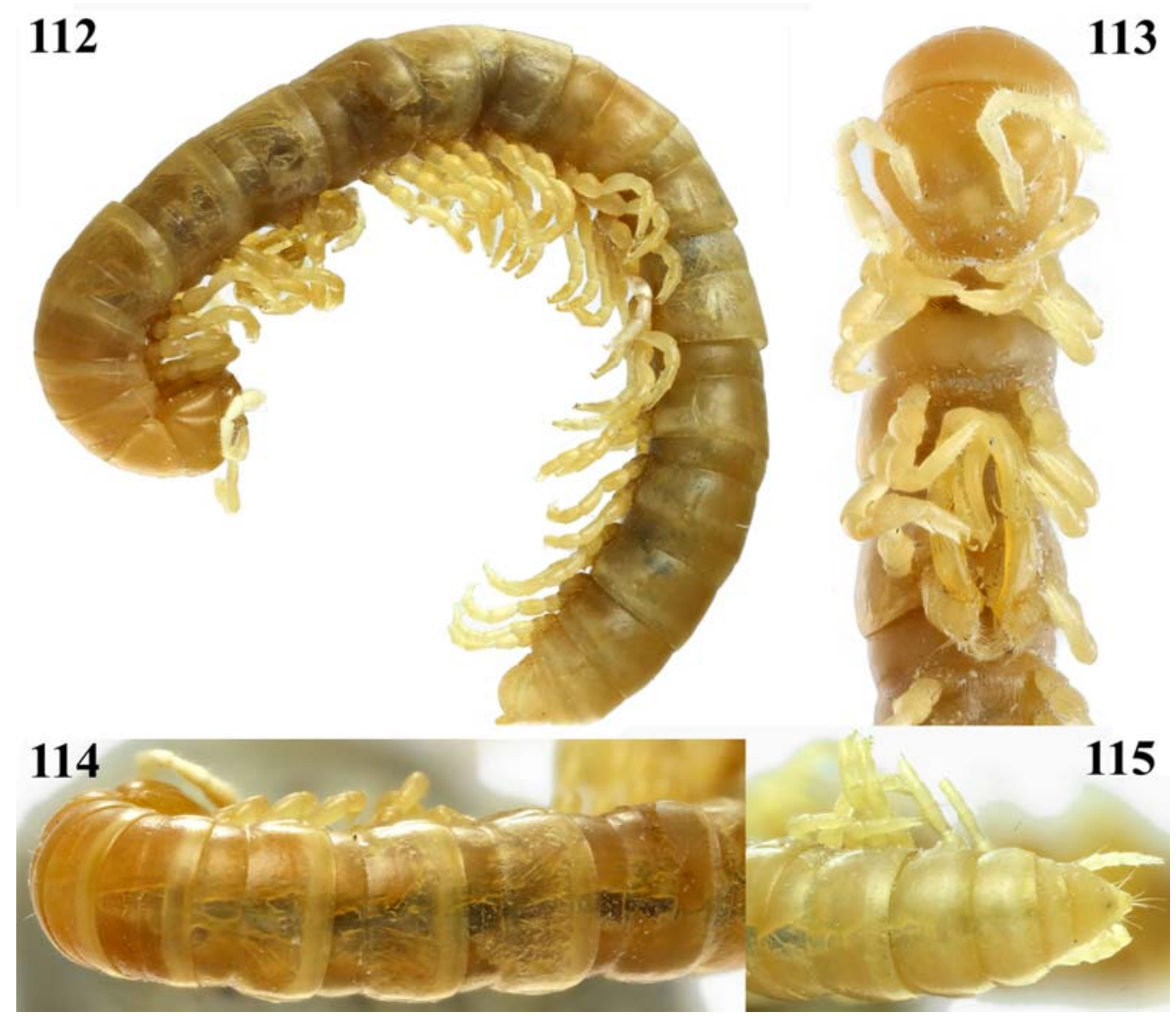

Figs 112-115. Beronodesmus pallidus sp.n., $0^{7}$ parartype: 112 - habitus, lateral view; 113 - anterior part of body, ventral view; $114 \& 115$ - middle and caudal parts of body, respectively, dorsal views. Photos taken by K. Makarov, not to scale.

Рис. 112-115. Beronodesmus pallidus sp.n., паратип о?: 112 - общий вид, сбоку; 113 - передняя часть тела, снизу; 114,115 соответственно средняя и задняя части тела, сверху. Фото сделаны К. Макаровым, без масштаба.

DESCRIPTION. Length of adults ca $16-17\left(0^{7}\right)$ or 18-19 mm (P), width of midbody pro- and metazonae $1.0-1.1$ and $1.1-1.2\left(\mathrm{O}^{7}\right)$ or $1.4-1.5$ and $1.5-1.6 \mathrm{~mm}$ (+), respectively. Holotype ca $16 \mathrm{~mm}$ long, 1.0 and 1.1 $\mathrm{mm}$ wide on pro- and metazonae, respectively. Coloration in alcohol entirely pallid to light yellow (Figs 112115 ), only distal half of antennomere 6 and all $7^{\text {th }}$ occasionally infuscate.

Body subcylindrical. In width, collum $<$ segment $2=$ $3<4<$ head $=5-16$; thereafter body very gently tapering. Clypeolabral region and frons sparsely setose, vertigial region bare. Antennae short and rather clearly clavate (Figs 112 \& 113), even in $\bigcirc^{7}$ only slightly extending back behind collum when stretched dorsally, a little shorter in 9 ; antennomeres 2-6 subequal in length, but $6^{\text {th }}$ clearly highest. Paraterga very poorly developed (Figs 112-116); a small ventrolateral, broadly rounded, rimmed lobule in collum; a small, rather thin, lowlying crest in segment 2 ; thereafter rounded bulges never produced caudad behind tergal margin, set low, mostly lying at about half of midbody height; calluses very poorly developed, but quite high/thick, in segments 3-18 delimited by a rather deep sulcus both dorsally and, only in caudal $1 / 3$ extent, ventrally, these sulci growing increasingly obliterate towards telson; paraterga 19 scarcely traceable. Ozopores lateral, invisible from above, lying inside a round pit at about $1 / 3$ of metaterga in front of caudal margin (Figs 112 \& 116). Body surface smooth and shining throughout, only below paraterga somewhat rugose to rugulose. Neither an axial line nor transverse metatergal sulci. Tergal setae short (ca $1 / 4^{\text {th }}$ of metatergal length), mostly abraded, on collum probably arranged in two transverse rows (likely $3+3$ and $2+2$ ) in front half, on a few following segments in a single transverse row of probably $2+2$ in front $1 / 3$ of metaterga, setation pattern being untraceable due to too vague insertion points (Figs 112-115). Stricture dividing pro- and metazonae rather narrow and shallow, finely striolate dorsally and dorsolaterally. Pleurosternal carinae rather distinct, caudally toothless ridges only in segment 2 , increasingly obliterate crests or lines in segments 3-7 $\left(\mathrm{O}^{7}\right)$, thereafter until about segment 10 traceable only as increasingly inconspicuous bulges, in ${ }^{+}$even more strongly reduced than in $\sigma^{7}$. Epiproct (Figs 115 \& 117) short, barely concave, subapical lateral papillae very small. 


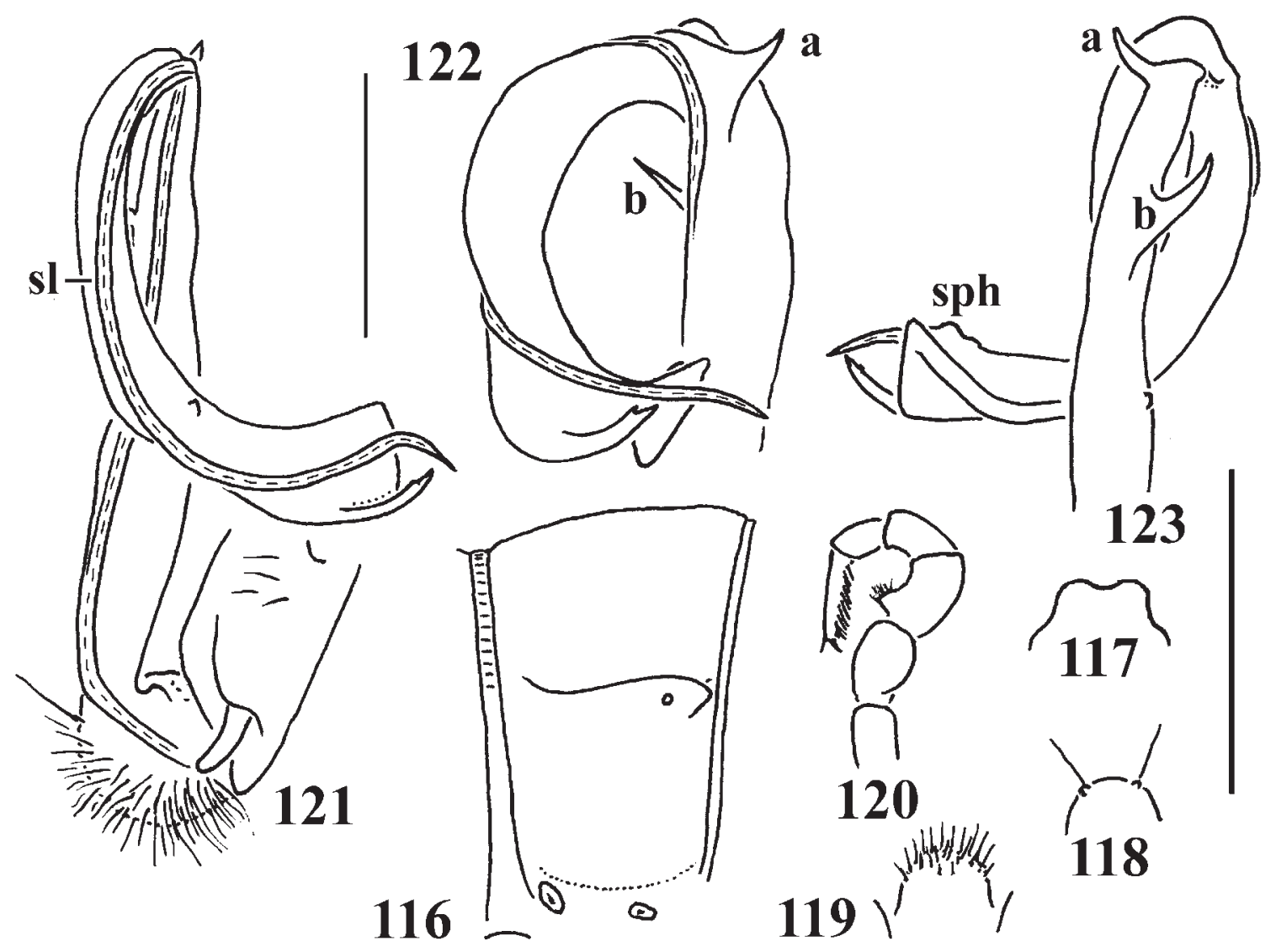

Figs 116-123. Beronodesmus pallidus sp.n., $0^{7}$ parartype: 116 - left half of segment 10, dorsal view; 117 — epiproct tip, dorsal view; 118 - hypoproct, ventral view; 119 - sternal lobe between coxae 4, caudoventral view; 120 - leg 1, lateral view; 121 - right gonopod, mesal view; $122 \& 123$ - distal half of right gonopod, dorsal and lateral views, respectively. Scale bars: $1.0(116-120)$ and 0.5 $\mathrm{mm}(121-123)$.

Pис. 116-123. Beronodesmus pallidus sp.n., паратип $0^{\text {? }}$ : 116 - левая половина сегмента 10, сбоку; 117 — кончик эпипрокта, сверху; 118 - гипопрокт, снизу; 119 - стернальная пластинка между тазиками 4, одновременно сзади и снизу; 120 - нога 1 , сбоку; 121 - правый гонопод, изнутри; 122, 123 - дистальная половина правого гонопода, соответственно сверху и сбоку. Масштаб 1,0 (116-120) и 0,5 мм (121-123).

Hypoproct (Fig. 118) nearly semi-circular, caudal 1+1 setae clearly separated, not borne on knobs.

Sternites without modifications, densely setose, nearly flat; a rather high, linguiform, setose lobe between $\sigma^{7}$ coxae 4 (Fig. 119). Legs rather short; $\sigma^{7}$ ones crassate and ca 1.2-1.3 times as long as midbody height (Figs 112 \& 113), $\bigcirc^{7}$ prefemora clearly swollen laterally until about legs 10 or 11 ; $\sigma^{7}$ femur 1 with an evident adenostyle (Fig. 120); tibial and tarsal brushes gradually thinning out until about $\sigma^{7}$ legs of segment 12 and 15 , respectively. + legs particularly slender and short, ca $0.8-0.9$ times as long as midbody height, devoid of modifications.

Gonopods (Figs 113 \& 121-123) fairly complex; coxite medium-sized, subcylindrical, with a few parabasal setae on medial face; prefemoral part as usual, densely setose, short, about 1/4 as long as femorite; the latter simple, slender, suberect, only very faintly attenuating distad, without evidence of torsion (= seminal groove running entirely on mesal side), devoid of a distolateral sulcus (= lacking a postfemoral portion), in distal part carrying two strong teeth $(\mathbf{a} \& \mathbf{b})$, one of which, apicolateral a, marking a clear-cut cingulum/ geniculation and the onset both of a flagelliform solenomere (sl) and a ribbon-shaped and bifid solenophore (sph), both sl and sph being subequally long and acuminate, somewhat longer than femorite, strongly curved mesad and subcircular.

ACKNOWLEDGEMENTS. I am extremely grateful to my friends Petar Beron and Pavel Stoev, both NMNHS, for allowing me to study the material treated here. The colour pictures were skillfully taken by K. Makarov, Moscow, Russia.

\section{References}

Attems C. 1936. Diplopoda of India // Memoirs of the Indian Museum. Vol.11. No.4. P.133-323.

Chen C., Golovatch S.I., Chang H.W. 2010. Revision of the Taiwanese millipede genus Chamberlinius Wang, 1956, with descriptions of two new species and a reclassification of the tribe 
Chamberlinini (Diplopoda, Polydesmida, Paradoxosomatidae, Paradoxosomatinae) // ZooKeys. Vol.72. P.1-21.

Golovatch S.I. 1984. Some new or less known Paradoxosomatidae (Diplopoda: Polydesmida) from India // Acta Zoologica Hungarica. Vol.30. Nos 3-4. P.327-352.

Golovatch S.I. 1990. Diplopoda from the Nepal Himalayas. The first Paradoxosomatidae (Polydesmida) // Spixiana. Bd.13. H.1. S.9-24.

Golovatch S.I. 1992. Diplopoda from the Nepal Himalayas. Some additional Paradoxosomatidae (Polydesmida) // Senckenbergiana biologica. Bd.72. H.1-3. S.183-203.

Golovatch S.I. 1994. Diplopoda from the Nepal Himalayas. Further Paradoxosomatidae (Polydesmida) // Senckenbergian biologica. Bd.73. H.1-2. S.163-182.

Golovatch S.I. 1996. Diplopoda from the Nepal Himalayas. Review of the genus Orophosoma Jeekel 1980 (Polydesmida: Paradoxosomatidae) // Senckenbergian biologica. Bd.76. H.12. S.163-184.

Golovatch S.I. 2009. On several new or poorly-known Oriental Paradoxosomatidae (Diplopoda: Polydesmida), VIII // Arthropoda Selecta. Vol.18. Nos 1-2. P. 1-7.

Golovatch S.I. 2014. On several new or poorly-known Orienta Paradoxosomatidae (Diplopoda: Polydesmida), XV // Arthropoda Selecta. Vol.23. No.1. P.1-19.

Golovatch S.I., Stoev P. 2013. The millipede family Paradoxosomatidae in the Philippines, with a description of Eustrongylosoma penevi sp.n., and notes on Anoplodesmus anthracinus
Pocock, 1895, recorded in Malaysia and Sri Lanka for the first time (Diplopoda, Polydesmida) // Biodiversity Data Journal, 1: 1-17, e957. doi: 10.3897/BDJ.1.e957

Jeekel C.A.W. 1953. Two new Strongylosomidae from Indochina (Diplopoda, Polydesmida) // Beaufortia. Vol.2. No.29. P.1-8.

Jeekel C.A.W. 1980a. The generic allocation of some littleknown Paradoxosomatidae from South-East Asia (Diplopoda, Polydesmida) // Revue suisse de Zoologie. T.87. Fasc.3. P.651-670.

Jeekel C.A.W. 1980b. On some little known Paradoxosomatidae from India and Ceylon, with the description of four new genera (Diplopoda, Polydesmida) // Beaufortia. Vol.30. No.8. P.163178.

Likhitrakarn N., Golovatch S.I., Panha S. 2013. The millipede genus Tetracentrosternus Pocock, 1895 (Polydesmida, Paradoxosomatidae, Alogolykinae, Alogolykini), with a description of the first, new species from Thailand// ZooKeys. Vol.358. P.1-10.

Nguyen Duc A. 2011. A review of the millipede tribe Tonkinosomatini (Diplopoda: Polydesmida: Paradoxosomatidae) from Vietnam // Zootaxa. Vol.3036. P.58-68.

Nguyen Duc A., Korsós Z. 2011. A revision of the millipede genus Riukiupeltis Verhoeff, 1939 (Diplopoda, Polydesmida, Paradoxosomatidae), with comments on the status of related species // ZooKeys. Vol.156. P.25-40.

Responsible editor K.G. Mikhailov 